THE EFFECT OF SKIPS ON THE GRAIN YIELD OF THE ADJACENT HILLS WITH MAIZE HYBRIDS UNDER DIFFERENT CONDITIONS 
Dit proefschrift met stellingen van

\section{LOTFI HINDI ALI HINDI,}

geboren te Dest Elashraf, Egypte (V.A.R.), 17 augustus 1928, is goedgekeurd door de promotor, Dr. Ir. J. C. DoRsT, hoogleraar in de teelt en de veredeling van landbouwgewassen.

De Rector Magnificus der Landbouwhogeschool,

W. F. EusvoogeL

Wageningen, 30 mei 1962 
$\sin 8201,329$

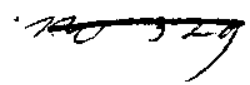

\title{
THE EFFECT OF SKIPS ON
}

\section{THE GRAIN YIELD OF THE ADJACENT HILLS}

\section{IN TRIALS WITH MAIZE HYBRIDS}

\section{UNDER DIFFERENT CONDITIONS}

(met een samenvatting in het Nederlands)

\author{
PROEFSCHRIFT \\ TER VERKRIJGING VAN DE GRAAD \\ VAN DOCTOR IN DE LANDBOUWKUNDE
}

OP GEZAG VAN DE RECTOR MAGNIFICUS, IR. W. F, EUSVOOGEL, HOOGLERAAR IN DE HYDRAULICA, DE BEVLOEIING,

DE WEG- EN WATERBOUWKUNDE EN DE BOSBOUWARCHITECTUUR,

TE VERDEDIGEN TEGEN DE BEDENKINGEN

VAN EEN COMMISSIE UIT DE SENAAT

VAN DE LANDBOUWHOGESCHOOL TE WAGENINGEN

OP WOENSDAG 4 JULI 1962 TE 16 UUR

DOOR

L. H. A. HINDI

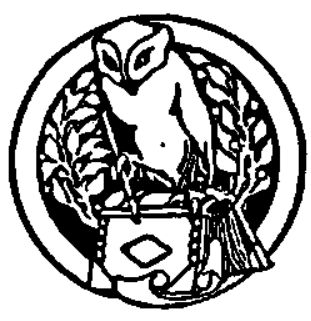

H. VEENMAN \& ZONEN N.V. - WAGENINGEN - 1962

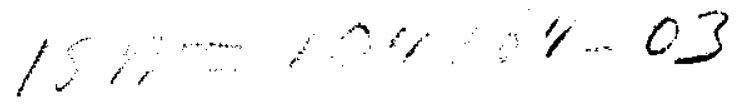




\section{Bibliotheek}

der

Landbouw Hogeschool

WAGENINGEN 


\section{THEOREMS}

In plant breeding work and variety trials the use of a formula to adjust the yield of plots containing missing hills is misleading.

This thesis

II

A high increase in the yield of the hills adjacent to skips indicates that the number of plants per unit-area is above the optimum.

This thesis

III

In countries where plant breeding is still in its early beginning research workers should place major emphasis on problems of direct interest to the farmers rather than concentrating their efforts on theoretical problems.

IV

In countries where potato production is dependent upon a limited number of imported varieties it is recommendable to test new seedlings of diverse origin raised in other countries in an early stage of development.

\section{V}

The limitation of the cultivated area in Egypt (U.A.R.) and the rapid increase in mechanization makes it very urgent to change the drainage system from open ditches to tile drainage.

\section{VI}

Rural broadcasts and educational films are very important tools in improving agriculture in newly developing countries as proved in Egypt (U.A.R.).

VII

In breeding new varieties of cotton for resistance against the pink bollworm Pectinophora gossypiella SAUNDERs full attention should be given to photoperiodism of both insect and plant.

\section{VIII}

Evolution in dutch agriculture justifies growing maize rather than fodder beet for silage. 


\title{
THE EFFECT OF SKIPS ON
}

\section{THE GRAIN YIELD OF THE ADJACENT HILLS \\ IN TRIALS WITH MAIZE HYBRIDS \\ UNDER DIFFERENT CONDITIONS}

\author{
THESIS \\ SUBMITTED IN PARTIAL FULFILMENT OF \\ THE REQUIREMENT FOR THE DEGREE OF \\ DOCTOR OF AGRICULTURAL SCIENCES \\ AT THE AGRICULTURAL UNIVERSITY OF \\ WAGENINGEN, HOLLAND \\ ON WEDNESDAY, 4 JULI 1962 at 16 o'Clock \\ BY
} L. H. A. HINDI

B.Sc. (Agr.), M.Sc. (Agr.) Cairo University

H. VEENMAN \& ZONEN N.V. - WAGENINGEN - 1962 
To the memory of my father To my wife

To my children 


\section{VOORWOORD}

Dit onderzoek werd verricht aan het Instituut voor Veredeling van Landbouwgewassen van de Landbouwhogeschool te Wageningen, Nederland. De schrijver betuigt zijn diepe erkentelijkheid aan zijn promotor, Prof. Dr. Ir. J. C. DoRsT, Directeur van het Instituut, voor diens leiding, zijn waardevolle adviezen en stimulerende critiek gedurende het onderzoek en voor het doornemen en verbeteren van het manuscript. Een woord van hartelijke dank komt ook toe aan Dr. F. P. FERWERDA voor zijn diepgaande belangstelling in dit onderzoek, zijn. nuttige wenken en waardevolle besprekingen en voor de tijd welke hij bereidwillig schonk, zowel aan het werk als aan het gereedmaken van het manuscript. Ook tegenover de overige leden van de staf van het Instituut, in de eerste plaats Dr. H. DE HAAN, die mij nimmer hun hulp onthielden, wanneer ik daarom vroeg, gevoel ik mij ten zeerste verplicht.

Mijn diepe erkentelijkheid richt zich ook tot Prof. Dr. N. H. KuIPER, hoogleraar in de wiskunde, Ir. S. H. Justesen, de heer M. Keuls en tevens tot de leden van de staf van de Afdeling wiskunde te Wageningen voor de gastvrijheid welke ik daar genoot, voor de nuttige wenken en de hulp welke ik gedurende het werk ondervond en voor de faciliteiten welke mij werden verleend bij het uitvoeren van de statistische analyse.

Een woord van bijzondere dank komt toe aan mijn collega Ir. M. S. RAouf en aan de heer N. G. UilensurG voor de vele moeite welke zij zich getroostten voor het corrigeren van de Engelse tekst. Ook aan mej. A. P. LooIJEN die het typen van tekst en tabellen voor haar rekening nam ben ik veel dank verschuldigd, evenals aan alle anderen die op enigerlei wijze aan de totstandkoming van dit werk bijdroegen.

Ook aan de Directie van het Internationaal Agrarisch Centrum ben ik grote dank verschuldigd voor de hulp en de vele faciliteiten welke deze instelling mij verleende gedurende ons verblijf in Nederland.

Aan de Regering van de Verenigde Arabische Republiek die mij de mogelijkheden verschafte om dit werk in Nederland te verrichten gevoel ik mij ten zeerste verplicht. 
This thesis will be published in Euphytica 11 (1962) No. 3 


\section{CONTENTS}

I. INTRODUCTION $\ldots \ldots \ldots$

II. ReView Of LITERAtURE . . . . . . . . . . . . . . . . . . . . . . 2

III. MAterial AND Methods . . . . . . . . . . . . . . . . . . . . . 5

1. Choice of the experimental material . . . . . . . . . . . . . . . 5

2. Design of experiments . . . . . . . . . . . . . . . . . . . . 7

3. Upkeep of the trial field . . . . . . . . . . . . . . . . . . . . 8

4. Observations and collection of data . . . . . . . . . . . . . . . 8

5. Arranging the data for the statistical analysis . . . . . . . . . . . 9

6. The statistical analysis . . . . . . . . . . . . . . . . . . 10

IV. Results . . . . . . . . . . . . . . . . . . . . ... . 12

A. The compensation per missing hill . . . . . . . . . . . . . . . 12

1. The experiments of 1959 . . . . . . . . . . . . . . . . . . 12

2. The experiments of 1960 . . . . . . . . . . . . . . . . . . . 14

3. The experiments of 1961 . . . . . . . . . . . . . . . . . . . 15

a. Experiment I with single cross (W $103 \times \mathrm{CH} 8)$. . . . . . 15

b. Experiment II with single cross (W $103 \times$ V3) . . . . . . . . 16

c. Experiment III with single cross (V3 $\times$ IVL5) . . . . . . . . . 16

d. The effect of the main factors and their interactions . . . . . 17

e. The effect of years . . . . . . . . . . . . . . . . . . . 19

f. Summary of the results of 1961 . . . . . . . . . . . . . . 20

B. The effect of orientation . . . . . . . . . . . . . . . . . . . . 21

V. Discussion . . . . . . . . . . . . . . . . . . . . . . 21

A. Compensation . . . . . . . . . . . . . . . . . . . . . 21

1. The effect of size and shape of skips . . . . . . . . . . . . . 22

2. The effect of stand . . . . . . . . . . . . . . . . . . . . . 23

3. The effect of nitrogen . . . . . . . . . . . . . . . . . . 24

4. The effect of hybrids . . . . . . . . . . . . . . . . . . . . 24

5. The effect of years and climatic conditions . . . . . . . . . . 25

B. The effect of orientation . . . . . . . . . . . . . . . . . . . 26

C. The use of adjustment formulae to correct plot yield for missing hills . 26

VI. Summary . . . . . . . . . . . . . . . . . . . . . . . . . . . . 28

VII. Conclusions . . . . . . . . . . . . . . . . . . . . . . . . . . 29

VIII. SAMENVAtTING . . . . . . . . . . . . . . . . . . . . . . . . . 30

IX. ACKNOWledgement . . . . . . . . . . . . . . . . . . . . . . 31

X. References . . . . . . . . . . . . . . . . . . . . . . . . 32 


\section{INTRODUCTION}

Every research worker tries to eliminate any sources of error in his experiments as far as he can. Experimental error may be introduced in variety trials because of the effect of skips or missing hills on the yield of the adjoining hills. Several methods have been used to prevent the occurrence of skips; such as using seeds of good quality, using the best techniques and agricultural practices, over-planting followed by thinning to the desired stand after emergence and, finally, transplanting. In spite of all these measures taken to prevent their incidence, missing hills constitute a reality in every experiment.

The occurrence of missing hills may be attributed to many factors among which the following ones are important:

1. The quality of seed.

2. Inherent varietal differences.

3. Mechanical factors such as damage during cleaning and cultivation of the field.

4. Weather conditions.

5. Diseases and pests.

6. Soil conditions.

In spite of the diversity of the factors that may be the cause of skips there are also many factors that must be taken into account before adjusting the plot yields. A skip is not always the same skip, since two skips may contain the same number of missing hills but yet they may differ in their shape and in the time at which they have occurred. Skips that occur at the beginning of the growing season have a big effect on the adjoining hills because the latter have sufficient time to utilize the space available and thus increase their yield. On the other hand, a skip that occurs in the later stages of growth has a small or even no influence on its neighbours. Furthermore two plots may contain the same number of missing hills but not the same number of skips which may be randomly distributed in the plot or located in a certain part of the plot.

In the literature detailed information concerning most of the points mentioned above is very scarce. Because of the importance of the effect of skips in field experiments and selection programmes the present study was suggested to contribute towards a better knowledge of:

1. The effect of missing hills or skips on the yield of the adjoining hills.

2. The influence of skip-size and shape, stand, nitrogen level, varieties, years and changes in climatic conditions from year to year, on the effect of skips.

3. The effect of orientation of the hills around a skip on their compensation for the loss in yield due to skips.

\section{REVIEW OF LITERATURE}

Several investigators have attempted to determine the effect of missing plants or missing hills on the yield of field trials. In their published works some empirical methods for adjusting the yield of plots containing missing hills have been suggested.

H. MAYER GMELIN (1910) described the method used in correcting the yield of sugar beet in plots containing less than $10 \%$ missing hills, at the firma Kuhn by adding 
$\frac{1}{2} \times$ number of missing hills $\times$ mean yield per plant. He did not, however, recommend this method of correction when a plot contained more than $10 \%$ missing hills. No mention was made as to why they had arrived to these conclusions.

FITCH and BENNET (cited after STEWART) working with potatoes stated that the hills on either side of a skip make up one half of the loss. They also asserted that skips in some varieties affect the yield of the second plant on either side.

STEWART (1919) found that potato plants which were directly adjacent to a skip outyielded the second neighbour by $23.2 \%$ on the average. He thus stated that in the case of a skip containing a single missing hill, the yield of the two adjoining hills will make up $46.4 \%$ of the loss in total yield, therefore skips of more than one hill would probably be a total loss except for a possible compensation of $46.4 \%$ of the yield of a single hill. STEWART (1921) also found that the increase in yield of the two plants adjoining a missing hill amounted to $53.8 \%$ of that of the second neighbour. Moreover, he found that he had obtained an improbable answer when investigating the relative influence of a single hill and a triple hill skip in increasing the yield of the adjoining plants, as the increase was greater for a single hill than for a triple hill skip.

LIVERMORE (1927) from experiments with potatoes reported an increase of at least $40 \%$ due to a single hill skip. On the other hand he gave an increase of at least $75 \%$ for a double hill skip, and concluded that the effect of missing hills is markedly influenced by soil and climatic conditions. ROEMER (1930) found that in sugar beet the two plants adjoining a skip on the average make up $50 \%$ of the loss. He also recommended the normal plant method for correcting the yield, but this method is elaborate and requires a large area in order to have enough normal plants. Moreover the adjusted yield is also higher than that of normal fields.

Another group of investigators used the method of replacing the missing hills by plants from another distinguished variety or even by plants of another species which have the same growing characteristics. BONNE (1952) replaced beets by turnips, RUNDFELDT (1958) replaced red cabbage by white cabbage and GiesBRECHT (1961) replaced maize by sunflower. At the time of harvest only the appropriate variety is harvested and the plot yield adjusted according to the number of plants which should have been present in the plot. All these methods appeared not to be very successful in most cases, unless this substitution was done in a very early stage and with plants grown in pots. Moreover, the act of replacing itself may disturb the neighbouring plants; also the competition of substitute plants may vary from that of the original crop.

KüPPER (1927) and VON SENGBUSCH (1928) used an empirical formula for correcting the yield of sugar beet, assuming that the average gain of the two plants adjoining a missing hill is 50 per cent. They remarked that even this 50 per cent appears to be highly inconsistent, and that it is important to have an idea about the average compensation for every experiment before adjusting the plot yields. They also indicated that, in some cases, a gap may be a disadvantage and it may depress the yield of the adjacent bills. Pedersen (1933) found that the percentage compensation decreases as the percentage of missing hills increases. SCHLÖsSER et al. (1961) found that the percentage compensation of sugar beet plants adjoining a skip varies from year to year, from place to place and according to the number and size of the skips. They also found a positive correlation between the number of plants and yield except in some cases 
where they got a negative or a no-sign-correlation. They recommended the use of the normal plant method which was suggested by ROEMER if space and labour are sufficiently available.

POPE (1947) conducted a large number of experiments with cotton and found that:

1. Skips occurring in the interior rows of multiple row plots are largely compensated by the increased production on end plants in the row containing the skip and by lateral compensation on the adjacent rows;

2. In single-row plots there is a definite reduction in yield due to skips, and this reduction appears to be substantially linear for distances more than three feet. Thus he suggested the following equation for adjusting the yield of single-row plots if skip distances are measured from the main stem of the plants.

$$
\text { Adjusted yield }=\text { actual yield } \times \frac{\text { total row length in feet }}{\text { total row length }-(\text { skip length }-3 \text { feet })}
$$

He also found that in some cases the correction obtained was either too great or too small. Gutı́rRez et al. (1954) with the purpose of finding out the relative influence of plant skips, missing row segments in experimental plots and commercial cultivation, as well as the effect of their distribution and total length on the yield of raw cotton, used three skip corrections during a period of three years. The experimental tests were based on a perfect stand check and a skip distance of $0.50,0.75,1.000,1.25,1.50,1.75$ and $2.00 \mathrm{~m}$ in the middle row of a three-row plot. They found that there was a maximum length of skips in the middle row at which both the two plants nearest to the skip increase their yield until they compensate the yield of the lost stand in the skip. They found that this distance was $0.75 \mathrm{~m}$. When a skip exceeds this distance a correction for the yield must be made according to the formula:

$$
Y_{c}=Y_{a} \frac{L_{a}}{L_{a}-\left(\mathrm{sd}_{1}-0.75\right)+\ldots \ldots+\left(\mathrm{sd}_{2}-0.75\right)}
$$

where $\mathrm{Y}_{c}=$ adjusted plot yield

$\mathrm{Y}_{a}=$ actual plot yield

$\mathbf{L}_{a}=$ actual length of the row-plot

$\mathbf{S}_{d}=$ skip length

KIESSELBACH (1923) found that 3-plant hills directly adjacent to incomplete hills with 0,1 and 2 plants yielded 114,107 and 102 per cent respectively of that of the normal 3-plant hills which were surrounded by 3-plant hills.

BREWBAKER and IMMER (1931) observed that the hills adjacent to a missing hill or to a hill with a reduced stand yielded more than hills surrounded by a full stand on all sides. The average yield of a three-plants hill increased by $12.6,7.0$ and $4.8 \%$ according to whether it was adjacent to 2 missing hills, to one missing hill or to a one 2-plant hill respectively over the yield of a three-plant hill surrounded by a full stand.

KIESSELBACH et al. (1933) tested the influence of irregular stand on the yield of maize for fourteen years, using a number of irregular stands that gave the same number of plant per acre. A uniform stand yielded on the average 49.9 bushels per acre, while the irregular stand of 2 and 4 plants per hill alternated regularly yielded 50.6 bushels per acre. The yield in bushels per acre was 49.3 for 1,3 and 5 plants per hill 
alternated and it was 50.0 bushels when 1,2,3,4 and 5 plants per hill were planted in regular sequence. The most variable stand of those mentioned above yielded 0.7 bushel or 1 per cent less than the uniform stand.

HuELSEN (1943) studied the same problem in sweet corn and found that the yield components were affected by stand irregularities. Moreover he compared the uniform stand of 2, 3 and 4 plants per hill and that of the same number alternated with missing hills and found that there was a significant decrease in the yield of the treatments containing missing hills as compared with the uniform stand. This decrease was $31.86,26.96$ and 22.60 per cent respectively, but it is not parallel with the decrease in stand due to the presence of missing hills which amounted to 50 per cent. This means that the hills adjacent to the missing hill have already made up a considerable part of the losses which were $18.14,23.04$ and 28.00 per cent respectively.

DUNGan and Nelson (unpublished, cited after Dungan et al. 1958) made an extensive study in Illinois on the effect of missing plants and missing hills on the grain yield of corn. They found that in a 3-plant per hill population 43 per cent of the loss in grain yield due to missing hills was made up by the increase in yield of the four nearest hills. When two plants were missing the remaining plant and the four nearest surrounding hills compensated 68 per cent of the loss. When one plant was missing, the remaining two plants and the four nearest neighbouring hills restored 89 per cent of the loss.

GIESBRECHT (1961) working on the effect of incomplete hills in comparative corn yield trials, found that significant increases in grain yield were obtained in 3-plant hills which were located directly adjacent to two missing hills. An increase in yield which almost attained the $5 \%$ level of significance was obtained in hills which were directly adjacent to only one missing hill. No significant gains in yield were obtained from hills located diagonally from missing hills or from those either directly or diagonally adjacent to the 1-plant or 2-plant hills. He also found that the practice of "spiking in" corn seed in the place of missing hills 2 weeks after planting (4-5 leaf stage) gave satisfactory competition to the surrounding hills. Moreover, no significant deviations from the check were obtained in all plots in both years. In 1959, he found that the hills directly adjacent to two "spiked in" hills yielded significantly more than the check.

\section{MATERIAL AND METHODS}

\section{Choice of the experimental material}

When studying the effect of missing hills or missing plants on the yield of the neighbouring hills, the homogeneity of the experimental material is of the utmost importance, since only individual hills can be compared.

Maize single crosses, especially when the parent inbred lines were under inbreeding for several seasons satisfy this requirement to a great extent and furthermore they are less susceptible to the serious diseases which frequently occur in other crops such as sugar beet or potato.

Four early single crosses namely $($ W $103 \times$ V3), $($ W103 $\times$ CH8), $($ V3 $\times$ IVL5) and $(\mathrm{WH} \times \mathrm{WJ})$ were selected for conducting the experiments. Single cross $(\mathrm{W} 103 \times \mathrm{V} 3)$ is a typical dent single cross of medium size with a height of about $170 \mathrm{~cm},(\mathrm{WH} \times \mathrm{WJ})$ 
1

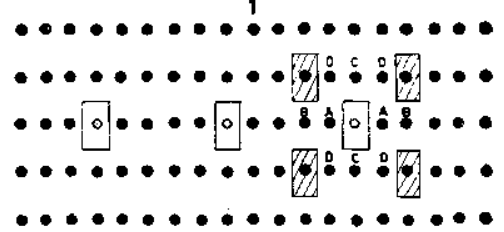

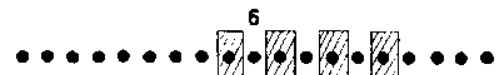

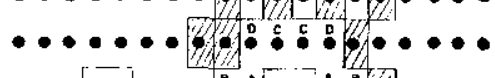

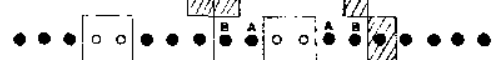

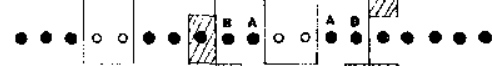

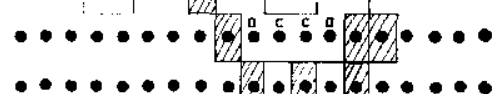

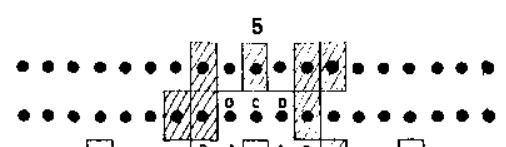

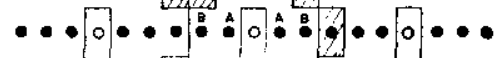
- * ol- *

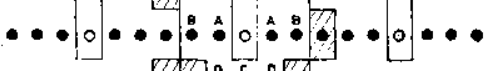

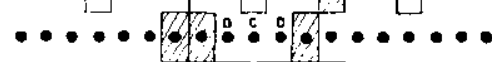
$\bullet \bullet \bullet \bullet \bullet \bullet \bullet \bullet \bullet \bullet \bullet \bullet \bullet \bullet \bullet$

8

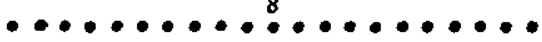
$\bullet \bullet \bullet \bullet \bullet \bullet \bullet \bullet \bullet \bullet \bullet \bullet \bullet \bullet \bullet \bullet \bullet \bullet$ $\bullet \bullet \bullet[00, \bullet \bullet \bullet, \bullet \bullet \bullet \bullet \bullet \bullet \bullet \bullet \bullet \bullet$

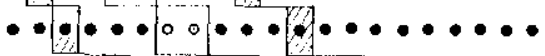
$\bullet \bullet \bullet \bullet \bullet \bullet \bullet\left[\circ \circ \bullet \bullet \bullet[]_{\bullet} \bullet \bullet \bullet \bullet \bullet\right.$

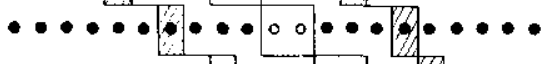
$\bullet \bullet \bullet \bullet \bullet \bullet \bullet \mid, \bullet \bullet \bullet \circ \bullet \bullet \bullet \bullet \bullet \bullet \bullet$

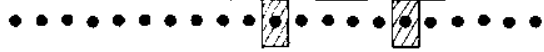
$\bullet \bullet \bullet \bullet \bullet \bullet \bullet \bullet \bullet \bullet \bullet \bullet \bullet \bullet \bullet \bullet \bullet \bullet \bullet \bullet$

$A=$ Direct neighbour in the row $B=$ Second neighbour in the row $C=$ Neighbour in the adjacent row $D=$ Hill diagonally adjacent
2

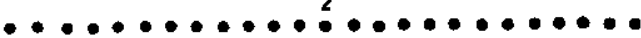

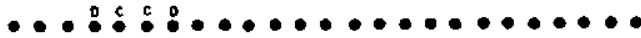
- : $\bullet \bullet \bullet: 55: \bullet \bullet \bullet \bullet \bullet \bullet \bullet \bullet \bullet \bullet \bullet \bullet \bullet \bullet \bullet \bullet \bullet \bullet$ $\bullet \bullet \bullet \bullet \bullet \bullet \bullet \bullet \bullet \bullet \bullet \bullet \bullet \bullet \bullet \bullet \bullet \bullet \bullet \bullet \bullet \bullet \bullet \bullet \bullet$

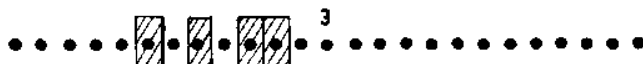

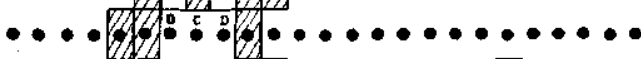

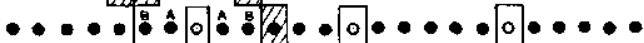

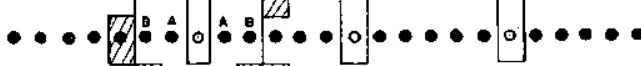

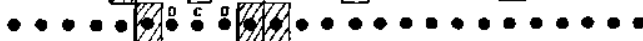
-

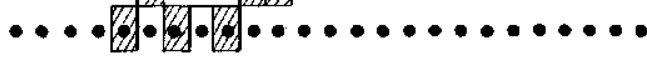
4 $\bullet \bullet \bullet \bullet \bullet \bullet \bullet \bullet \bullet \bullet \bullet \bullet \bullet \bullet \bullet \bullet \bullet \bullet \bullet \bullet \bullet \bullet$ $\bullet \bullet: 5: 5: \circ \bullet \bullet \bullet \bullet \bullet \bullet \bullet \bullet \bullet \bullet \bullet \bullet \bullet \bullet \bullet \bullet \bullet$

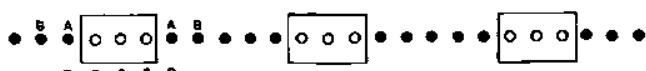

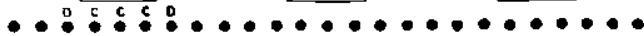
$\bullet \bullet \bullet \bullet \bullet \bullet \bullet \bullet \bullet \bullet \bullet \bullet \bullet \bullet \bullet \bullet \bullet \bullet \bullet \bullet \bullet \bullet \bullet \bullet \bullet$

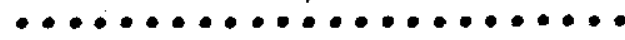

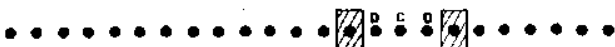

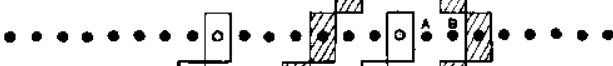
$\cdots \cdots \cdots \cdot 0 \cdot \cdots$

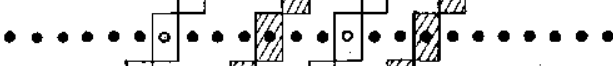
$\cdots \cdots \bullet \cdot 0 \cdot \cdots$

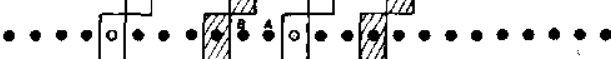

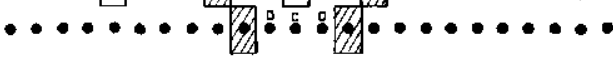
$\bullet \bullet \bullet \bullet \bullet \bullet \bullet \bullet \bullet \bullet \bullet \bullet \bullet \bullet \bullet \bullet \bullet \bullet \bullet \bullet \bullet \bullet \bullet$

Normal hills

$\square=$ skips 
is a dent single cross with an average plant height of about $2 \mathrm{~m},(\mathrm{~W} 103 \times \mathrm{CH} 8)$ is a dent-flint single cross with a strong vegetative growth and a plant height of about $220 \mathrm{~cm}$ and (V $3 \times$ IVL5) is a typical dent flint cross of medium size but characterised by the production of many tillers when sown with a stand of one plant per hill.

The quantity of seed available at that time did not permit the layout of large experiments, and for this reason a number of small experiments were carried out to get a preliminary idea about the effect of missing hills. During the growing seasons 1959 and 1960 an extensive crossing programme was carried out and an ample quantity of seed became available for the experiments of the growing seasons of 1960 and 1961.

\section{Design of experiments}

The experiments were sown at the experimental farm "Wageningse Berg" of the 'Instituut voor Veredeling van Landbouwgewassen' in 1959, 1960 and 1961 with the exception of one experiment with single cross (V3 $\times$ IVL5) which was sown at the Dorskamp farm in 1961.

The initial work was started in the growing season of 1959. As stated above, due to the lack of sufficient seed, only a number of small experiments could be conducted in order to test for the effect of different types of skips on different hybrids and stands.

In the first trial a single cross (V3 $\times$ IVL5) was used to get a preliminary idea about the effect of one missing hill (1)*, two missing hills in one row (2), two missing hills in two adjacent rows (3), three missing hills in one row (4) and three missing hills in three adjacent rows (5). These types of skips are illustrated diagrammatically on page 6 as types (1), (2), (3), (4) and (5) respectively. In the second trial another type of skip having the advantage that a large number of types of neighbours could be tested at the same time was used. This skip which will be referred to as a "slanting skip" is illustrated at (7) and (8) of the diagram page 6 . The third experiment was carried out to study the effect of a large skip, four missing hills in two rows (6), in the presence of a stand of one plant/hill or two plants/hill. The same was repeated in the fourth trial but the skips involved either one missing hill (1) or two missing hills in one row (2).

In 1960, three trials were carried out. The first trial involved the skips given in (1), (2) and (3) of the diagram and each type of skips was carried out with two levels of nitrogen namely 80 and 120 kilograms per hectare. The "slanting skips", (7) and (8), were used in the second trial but the size of the skip was reduced to two rows instead of five. Also three different stands were used. This experiment had, however, to be discontinued because the plants were severely attacked by the frit fly. The third trial was the same as that of 1959 without any modification. Nevertheless the "slanting skips" were discarded in 1961 because they were complicated and required a big area and a large number of labour. In addition the number of hills obtained from every type of the neighbours was widely different that the comparison between them was not reasonable.

From the experience gained in 1959 and 1960 two types of skips namely, (5) and (6) in the diagram page 6 , were used. Three factorial experiments with similar design were carried out in 1961 . The design was a $2^{3}$ factorial and the treatments were two

* Figures in parentheses indicate the types of skips in the diagram. 
types of skips (5) and (6), two stands of one or two plants/hill and two levels of nitrogen 60 or 120 kilograms per hectare. The first experiment was sown to the hybrid $(\mathrm{W} 103 \times \mathrm{CH} 8)$, the second $(\mathrm{W} 103 \times \mathrm{V} 3)$ and the third to $(\mathrm{V} 3 \times$ IVL5). Within each of the eight plots involved in each experiment, the type of skip assigned was replicated 18 to 22 times.

\section{Upkeep of the trial field}

In the Netherlands sowing of maize is carried out in the last week of April. The field has to be prepared for sowing some days before that time, and to avoid the risk of having some plants damaged during cleaning and cultivation the field was sprayed with ATRAZIN as a pre-emergence weed killer. When three kilograms per hectare were used, the field remained satisfactorely clean for about eight weeks. The seeds were also treated just before sowing with AATIRIT (mixture of TMTD and Lindane) for protection against seed borne fungi and cut worms.

The planting distances were $70 \mathrm{~cm}$ between rows and $35 \mathrm{~cm}$ between hills in all cases, with the exception of trials $I$ and $I$ in 1959 and trial $I$ in 1960 where the distances were $55 \times 30 \mathrm{~cm}$. Rows were made in both directions with the proper distances. Afterwards, four or five kernels per hill were sown at the intersection of the rows. After sowing the appropriate amount of nitrogen was added. In 1959 and 1960 the fields were covered with nets during the first four weeks after sowing for protection against bird damage. In 1961 nets were not used because the fields had to be sprayed with DDT once every week to avoid the attack of the frit fly, and the only way of keeping the birds out was to have a watchman on the field from dawn till dusk during the first four critical weeks after emergence. Thinning of the hills to the proper stand was done five weeks after sowing and at the same time skips were artificially made.

The summer of 1959 was an exceptionally dry season and the effect of drought was severe especially on the sandy soil where the experiments were carried out. Therefore irrigation was inevitable and the field was sprinkled once every ten days during May and June. Moreover sprinkling was used once in the beginning of May 1960.

\section{Observations and collection of data}

Four weeks before harvest every hill in the field was tagged, and data were collected on the plants of a sample of 400 hills in each plot concerning plant height and ear height in the trials of 1961 . In 1959 and 1960 every hill was harvested separately and its yield was put in a perforated paper bag-carrying its number; moreover, the label containing the number of the hill was also put in the bag. These perforated bags were used to facilitate the circulation of the air in the bags while they were kept in the drier. In 1961, from the experience gained in 1959 and 1960, all the hills surrounding a skip were harvested separately, except those which are called normal hills (see the diagram). These were harvested together and put in a jute bag given the number of the skip. This was done for two reasons, first because it was found that after keeping maize in the drier for two weeks no differences in the moisture content had been observed and secondly, this would reduce the number of hills to be harvested separately in 1960 from 20 thousand to about 10 thousand and would save a lot of time, labour and space. Later the bags were arranged in wooden boxes and put in the drier where hot air was blown in at $50^{\circ} \mathrm{C}$ for two weeks. During this period the order of the boxes was 
interchanged every two or three days in order to achieve the same moisture equilibrium. Shelling was done for every hill separately and for the normal plants collectively and the yields of every hill was put in a paper bag given its number. Afterwards, the shelled kernels were kept in a room with constant temperature for two weeks to achieve the same moisture equilibrium. Then data were collected on the kernel weight of the individual hills and the total yield of the normal hills of each skip.

In 1959 and 1960, two samples of 10 grams each were taken from the yield of every hill just after weighing for determining the moisture content in order to be able to adjust the yields afterwards to $15.5 \%$ moisture content. The moisture determinations were carried out by grinding the kernels, weighing, drying for 14 hours at $104^{\circ} \mathrm{C}$ and weighing again. These determinations amounted to 7 and 10 thousands in 1959 and 1960 respectively and no remarkable differences between the hills were obtained after the maize was kept in the drier for two weeks. Therefore, in 1960 the material was kept in the drier for two weeks and no moisture determinations were carried out, since the number of hills amounted to 17 thousands in that year, which would have required much time, labour and equipment. Only a random sample of 200 hills was tested in 1961, and no differences in moisture content have been observed.

\section{Arranging the data for the statistical analysis}

After the yield data were collected the hills were divided into the following types for every skip separately as shown diagrammatically on page 6;

A. the direct neighbour in the row

B. the second neighbour in the row

C. the neighbour in the adjacent row

D. hills diagonally adjacent

N. the normal hills (hills surrounded on all sides by full stand and at least two hills far from the skip in the row).

Moreover, types $\mathrm{A}$ and $\mathrm{C}$ were both split up into two subtypes according to the position of the hill from the skip i.e. whether it was situated to the north or to the south. The yield of the individual hills related to every skip were arranged in tables from which the total yield and the mean yield of each type of hill for every skip were obtained (as an example see table 1). Because of the wide differences in the average yield among the treatments and hybrids it seemed desirable to convert the actual yield to a percentage of the average yield of the normal hills in order to simplify the comparison between them. Afterwards the average percentage increase in grain yield per hill was calculated as follows:

$$
\begin{aligned}
& \text { Average percentage } \\
& \text { increase in yield }
\end{aligned}=\frac{\text { mean yield of the type }}{\text { mean yield of the normal hills }} \times 100-100
$$

From these average percentage increases the total increase in yield (positive or negative) of the hills surrounding a skip was calculated, and this total was divided by the number of missing hills per skip. The quotient thus derived shows how much the hills adjoining a skip compensated for the loss of a single hill. Furthermore, comparisons were made between the hills situated to the north or to the south of a skip, 


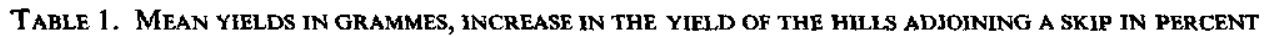
OF THE NORMAL HILLS AND THE COMPENSATION PER MISSING HILL

\begin{tabular}{|c|c|c|c|c|c|c|c|c|c|c|c|c|}
\hline \multirow{2}{*}{$\begin{array}{l}\text { Skip } \\
\text { no }\end{array}$} & \multicolumn{5}{|c|}{$\begin{array}{l}\text { Mean yields in grammes } \\
\text { per hill }\end{array}$} & \multicolumn{5}{|c|}{$\begin{array}{l}\text { The increase in yield expressed in } \\
\text { percent. of the normal hills }\end{array}$} & \multicolumn{2}{|c|}{$\begin{array}{l}\text { The } \\
\text { compensation }\end{array}$} \\
\hline & $\mathbf{N}$ & A & B & C & D & $\mathrm{N}$ & A & B & $\mathrm{C}$ & D & Total & \begin{tabular}{|c} 
Per \\
missing \\
hill
\end{tabular} \\
\hline 1 & 164 & 179 & 166 & 212 & 144 & 100 & 9.14 & 1.20 & 28.95 & -12.20 & 108.40 & 27.10 \\
\hline 2 & 156 & 206 & 185 & 157 & 170 & 100 & 31.75 & 18.60 & 0.30 & 9.00 & 238.60 & 59.60 \\
\hline 3 & 154 & 208 & 166 & 162 & 178 & 100 & 34.75 & 7.80 & 4.85 & 15.60 & 252.00 & 63.00 \\
\hline 4 & 162 & 241 & 173 & 179 & 144 & 100 & 48.50 & 6.80 & 10.20 & -11.10 & 217.40 & 54.30 \\
\hline 5 & 157 & 223 & 141 & 164 & 132 & 100 & 41.70 & -10.20 & 4.15 & -15.90 & 79.00 & 19.70 \\
\hline 6 & 148 & 164 & 171 & 187 & 148 & 100 & 10.45 & 15.50 & 26.00 & 0.00 & 207.80 & 51.90 \\
\hline 7 & 155 & 154 & 160 & 163 & 153 & 100 & -0.65 & 3.20 & 4.85 & -1.30 & 24.40 & 6.10 \\
\hline 8 & 160 & 211 & 186 & 167 & 183 & 100 & 31.85 & 16.30 & 4.40 & 15.60 & 272.60 & 68.10 \\
\hline 9 & 150 & 217 & 153 & 175 & 175 & 100 & 44.65 & 2.00 & 16.65 & 16.70 & 270.70 & 67.70 \\
\hline 10 & 143 & 191 & 189 & 144 & 182 & 100 & 33.60 & 32.20 & 0.35 & 27.30 & 373.80 & 93.40 \\
\hline 11 & 156 & 170 & 162 & 175 & 166 & 100 & 9.00 & 3.80 & 11.85 & 6.40 & 124.20 & 31.10 \\
\hline 12 & 153 & 199 & 188 & 164 & 163 & 100 & 30.05 & 22.90 & 7.20 & 6.50 & 266.60 & 66.60 \\
\hline 13 & 153 & 185 & 204 & 151 & 140 & 100 & 21.00 & 33.30 & -1.30 & -8.50 & 177.80 & 44.50 \\
\hline 14 & 162 & 178 & 180 & 165 & 171 & 100 & 9.90 & 11.10 & 1.55 & 5.60 & 147.20 & 36.80 \\
\hline 15 & 149 & 194 & 168 & 152 & 203 & 100 & 29.90 & 12.80 & 2.00 & 36.20 & 323.40 & 80.80 \\
\hline 16 & 150 & 201 & 164 & 136 & 151 & 100 & 33.65 & 9.30 & -9.65 & 0.70 & 136.00 & 34.00 \\
\hline 17 & 140 & 209 & 171 & 164 & 149 & 100 & 48.90 & 22.10 & 17.15 & 6.40 & 378.20 & 94.50 \\
\hline 18 & 135 & 161 & 180 & 158 & 193 & 100 & 19.25 & 33.30 & 17.05 & 43.00 & 450.40 & 112.60 \\
\hline 19 & 169 & 179 & 165 & 156 & 188 & 100 & 6.25 & -2.40 & -7.95 & 11.20 & 28.40 & 7.10 \\
\hline 20 & 157 & 167 & 176 & 163 & 177 & 100 & 6.05 & 12.10 & 3.50 & 12.70 & 137.40 & 34.30 \\
\hline 21 & 159 & 178 & 173 & 170 & 163 & 100 & 11.65 & 8.80 & 6.90 & 2.50 & 119.40 & 29.80 \\
\hline Mean & 154 & 191 & 172.2 & 164.5 & 165.5 & 100 & 24.40 & 12.40 & 7.10 & 7.90 & & 51.57 \\
\hline \multicolumn{7}{|c|}{$\begin{array}{l}A=\text { Direct neighbour in the row } \\
\mathbf{B}=\text { Second neighbour in the row } \\
\mathbf{C}=\text { Neighbour in the adjacent rows }\end{array}$} & \multicolumn{6}{|c|}{$\begin{array}{l}\mathrm{D}=\text { Hills diagonally adjacent } \\
\mathrm{N}=\text { Normal hills }\end{array}$} \\
\hline
\end{tabular}

Every figure is an average of 4 hills with the exception of the Normal hills where it is the average of 15 hills.

as well as to the west and to the east. This was done for hills of the types $\mathrm{A}$ and $\mathrm{C}$. The comparison was made by taking the quotient resulting from dividing the mean yield of the hills situated to the north or the west by those situated to the south and east, respectively, for every skip multiplied by 100 . Afterwards, the mean of all the skips in every plot was taken to represent the plot.

\section{The statistical analysis}

After the tables were arranged in the manner described above, the data were statistically analysed. In the first place it was necessary to test for an increase in the yield of the hills adjoining a skip. In the second place the effect of the orientation of the hills from the skip on the yield was tested, and finally a test was made for the effect of stand, size and shape of the skips, nitrogen and hybrids on the yield of the hills surrounding a skip as well as their effect on the compensation per missing hill. 
TABLE 2. THE EFFECT OF ORIENTATION OF THE HILLS AROUND A SKIP EXPRESSED AS PERCENTAGE OF THE YIELD OF THE HILLS SITUATED TO THE SOUTH OR TO THE EAST

\begin{tabular}{|c|c|c|c|c|c|c|}
\hline \multirow{3}{*}{$\begin{array}{l}\text { Skip } \\
\text { No. }\end{array}$} & \multicolumn{6}{|c|}{ Yields } \\
\hline & \multicolumn{3}{|c|}{ A } & \multicolumn{3}{|c|}{ C } \\
\hline & West & East & $\mathbf{W} / \mathbf{E}$ & North & South & $\mathrm{N} / \mathrm{S}$ \\
\hline 1 & 182 & 176 & 103.4 & 213 & 210 & 101.5 \\
\hline 2 & 207 & 204 & 101.4 & 149 & 164 & 90.8 \\
\hline 3 & 211 & 204 & 103.4 & 173 & 150 & 115.3 \\
\hline 4 & 219 & 262 & 83.6 & 167 & 190 & 87.8 \\
\hline 5 & 236 & 209 & 112.9 & 183 & 144 & 127.1 \\
\hline 6 & 156 & 171 & 91.3 & 205 & 168 & 122.0 \\
\hline 7 & 151 & 157 & 96.2 & 163 & 162 & 100.7 \\
\hline 8 & 221 & 201 & 109.9 & 162 & 172 & 94.2 \\
\hline 9 & 224 & 210 & 106.6 & 180 & 170 & 105.9 \\
\hline 10 & 213 & 169 & 126.1 & 143 & 144 & 99.3 \\
\hline 11 & 187 & 153 & 122.2 & 173 & 176 & 98.3 \\
\hline 12 & 205 & 193 & 106.3 & 170 & 158 & 107.5 \\
\hline 13 & 188 & 182 & 103.3 & 187 & 115 & 162.5 \\
\hline 14 & 155 & 201 & 77.1 & 195 & 134 & 145.6 \\
\hline 15 & 169 & 218 & 77.5 & 149 & 155 & 96.1 \\
\hline 16 & 236 & 165 & 143.0 & 127 & 144 & 88.2 \\
\hline 17 & 204 & 213 & 95.8 & 177 & 151 & 117.1 \\
\hline 18 & 186 & 136 & 136.8 & 208 & 108 & 192.6 \\
\hline 19 & 198 & 161 & 123.0 & 172 & 139 & 123.7 \\
\hline 20 & 139 & 194 & 71.6 & 203 & 122 & 166.4 \\
\hline 21 & 161 & 194 & 83.0 & 181 & 159 & 113.8 \\
\hline Mean & & & 103.6 & & & 116.97 \\
\hline
\end{tabular}

$A=$ Direct neighbour in the row.

$\mathbf{C}=$ Neighbour in the adjacent row.

The null hypothesis was that there was no increase in the yield of the hills adjoining a skip over the average yield of the normal hills, or in other words that the average increase (positive or negative) of their yield was equal to zero. In testing this hypothesis, the objective was to determine whether the presence of a skip had increased the yield of the adjoining hills. Therefore a separate analysis of variance was done for every type of neighbours in each plot and Student's test was used in testing the hypothesis. A similar test was carried out for the effect of the orientation to determine whether the quotients were different from 100 (table 2).

Moreover in 1961, an additional analysis of variance was carried out for each of the three experiments separately, as well as for experiments I and II or I, II and III as a factorial experiment collectively. 


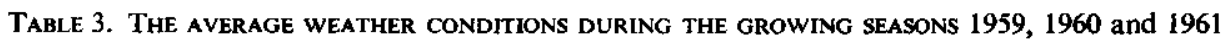

\begin{tabular}{|c|c|c|c|c|c|c|c|c|c|c|c|c|}
\hline \multirow{4}{*}{ Month } & \multicolumn{12}{|c|}{ Growing season } \\
\hline & \multicolumn{4}{|c|}{1959} & \multicolumn{4}{|c|}{1960} & \multicolumn{4}{|c|}{1961} \\
\hline & \multicolumn{2}{|c|}{ Temperature } & \multirow{2}{*}{$\begin{array}{c}\text { Cloud- } \\
\text { ness }\end{array}$} & \multirow{2}{*}{$\begin{array}{c}\text { Rain- } \\
\text { fall } \\
\text { m.m. }\end{array}$} & \multicolumn{2}{|c|}{ Temperature } & \multirow{2}{*}{$\begin{array}{c}\text { Cloud- } \\
\text { ness }\end{array}$} & \multirow{2}{*}{$\begin{array}{c}\text { Rain- } \\
\text { fall } \\
\text { m.m. }\end{array}$} & \multicolumn{2}{|c|}{ Temperature } & \multirow{2}{*}{$\begin{array}{c}\text { Cloud- } \\
\text { ness }\end{array}$} & \multirow{2}{*}{$\begin{array}{c}\text { Rain- } \\
\text { fall } \\
\text { m.m. }\end{array}$} \\
\hline & Max. & Min. & & & Max. & Min. & & & Max. & Min. & & \\
\hline April & 15.4 & 6.2 & 22.0 & 71.8 & 14.3 & 4.4 & 21.1 & 18.3 & 15.5 & 7.4 & 22.1 & 98.5 \\
\hline May & 19.4 & 8.4 & 15.1 & 11.2 & 19.2 & 8.7 & 18.5 & 43.0 & 15.9 & 7.4 & 21.3 & 66.2 \\
\hline June & 22.9 & 10.8 & 16.9 & 21.4 & 22.4 & 12.2 & .17 .6 & 51.4 & 21.6 & 11.5 & 18.8 & 44.3 \\
\hline July & 25.4 & 13.2 & 14.1 & 82.8 & 20.3 & 12.5 & 25.1 & 131.0 & 20.5 & 12.2 & 22.7 & 96.6 \\
\hline August & 24.1 & 13.4 & 17.9 & 39.8 & 21.1 & 12.6 & 23.6 & 159.7 & 21.2 & 12.7 & 22.5 & 102.5 \\
\hline September & 22.4 & 9.6 & 11.3 & 5.0 & 18.8 & 10.5 & 19.4 & 58.1 & 22.2 & 13.6 & 18.7 & 87.9 \\
\hline October & 17.7 & 6.5 & 14.5 & 54.1 & 14.4 & 8.4 & 25.5 & 164.5 & 15.8 & 8.3 & 18.3 & 83.5 \\
\hline $\begin{array}{l}\text { Total } \\
\text { Average }\end{array}$ & 21.5 & 9.7 & 15.9 & $\begin{array}{r}286.1 \\
40.9\end{array}$ & 18.2 & 9.9 & 21.5 & $\begin{array}{r}626.0 \\
89.4\end{array}$ & 18.9 & 10.5 & 20.6 & $\begin{array}{r}579.5 \\
82.5\end{array}$ \\
\hline
\end{tabular}

Cloudiness: $\mathrm{O}=$ clear sky; $30=$ cloudy the whole day.

These data were obtained from the Laboratory of Physics and Meteorology at Wageningen.

\section{RESULTS}

\section{A. The compensation per missing hill}

1. The experiments of 1959

The experiments carried out in 1959 were very small in size and conducted to give an impression about the effect of missing hills and the effect of different stands on the yield of the hills adjoining skips. The summer of 1959 was characterised by an excess of sunshine and a lack of rainfall; in fact it was the driest summer on record for more than a century (see table 3). The effect of drought was severe especially on the sandy soil where these experiments were located. Moreover the number of hills in each

TABle 4. ExPERIMENT 1 (1959) WITH SINGLe Cross (V3 $\times$ IVL5). The INCREASE IN THE Yield OF THE HILLS ADJOINING SKIPS EXPRESSED AS PERCENTAGE OF THE YIELD OF THE NORMAL HILLS

\begin{tabular}{|c|c|c|c|c|c|c|c|}
\hline \multirow{2}{*}{\multicolumn{2}{|c|}{ Skips }} & \multicolumn{5}{|c|}{ Types of hills adjoining skips } & \multirow{3}{*}{$\begin{array}{l}\text { Compen- } \\
\text { sation per } \\
\text { missing hill }\end{array}$} \\
\hline & & \multirow{2}{*}{ 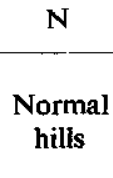 } & A & B & C & C & \\
\hline Type & Size & & $\begin{array}{l}\text { Direct } \\
\text { neighbour } \\
\text { in the row }\end{array}$ & $\begin{array}{l}\text { Second } \\
\text { neighbour } \\
\text { in the row }\end{array}$ & $\begin{array}{l}\text { Neighbour } \\
\text { in the } \\
\text { adjacent row }\end{array}$ & $\begin{array}{c}\text { Hills } \\
\text { diagonally } \\
\text { adjacent }\end{array}$ & \\
\hline (1) & 1 & 100 & 11.6 & -0.8 & 2.0 & -5.6 & 3.2 \\
\hline (2) & 2 & 100 & -1.2 & $17.0^{*}$ & 3.0 & 13.6 & 49.0 \\
\hline (3) & 2 & 100 & $24.4^{*}$ & 8.4 & 5.2 & -0.2 & 70.4 \\
\hline (4) & 3 & 100 & 1.8 & -2.8 & 4.4 & -4.8 & 1.7 \\
\hline (5) & 3 & 100 & $18.2^{* *}$ & 6.4 & 8.2 & 2.8 & $58.5^{*}$ \\
\hline
\end{tabular}

* Significantly different from zero at the $5 \%$ level.

** Significantly different from zero at the $1 \%$ level.

Figures in parenthesis indicate the types of skips in the diagram. 
TABLe 5. EXPeriment 2 (1959) WITH SINGLe CROSS (W103 $\times$ V3). THE INCREASE IN THE Yield OF THE HILLS ADJOINING SKIPS EXPRESSED AS PERCENTAGE OF THE YIELD OF THE NORMAL, HILLS

\begin{tabular}{l|c|c|c|c|c|c|c|c}
\hline \multicolumn{2}{c|}{ Slanting skips } & \multicolumn{7}{c}{ Types of hills adjoining skips } \\
\hline Type & Size & $\begin{array}{c}\text { Normal } \\
\text { hills }\end{array}$ & $\mathrm{A}$ & $\mathrm{A}^{\prime}$ & $\mathrm{B}$ & $\mathrm{C}$ & $\mathrm{C}^{\prime}$ & $\mathrm{D}$ \\
\hline$(7)$ & 1 & 100 & $18.2^{*}$ & $10.3^{*}$ & -1.0 & -1.0 & - & 0.8 \\
$(8)$ & 2 & 100 & 5.6 & $22.7^{* *}$ & -1.2 & 4.3 & 6.6 & 3.8
\end{tabular}

* Significantly different from zero at the $5 \%$ level.

** Significantly different from zero at the $1 \%$ level.

Figures in parenthesis indicate the types of skips in the diagram.

experiment was low because the quantity of single cross seed was too limited to permit the lay-out of larger experiments. Therefore the results of 1959 can be considered as exploratory data just to give a preliminary idea about the effect of missing hills. Although there were some exceptions, generally it was found that there was an increase in the grain yield of the hills located directly adjacent to the skips in the row over that of the normal hills and that it was significantly higher than zero as shown in the tables 4, 5, 6 and 7. Table 4 also shows the effect of the size and shape of skips on the yield of the direct neighbours. The increase was significant when the missing hills of a multiple-hill skip were not included in one row. As for the slanting skips, as in table 5, there was only a significant increase in the yield of the direct neighbours in the row (A). In the third experiment (table 6) it was found that the large skips have decreased rather than increased the yield of all the hills adjoining them and that the decrease was significantly less than zero at the $1 \%$ level. The effect of stand is seen from the results of experiment 4 (table 7). An increase in the yield of the direct neighbour was significantly larger than zero at the $1 \%$ level when a stand of two plants/hill was used.

TABLE 6. EXPeriment 3 (1959) WITH SINGLE CROSS (W103 $\times$ V3). THE INCREASE IN THE yield OF the HLLS ADJOINING SKIPS EXPRESSED AS PERCENTAGE OF THE. YIELD OF THE NORMAL HILLS

\begin{tabular}{|c|c|c|c|c|c|c|c|c|}
\hline \multirow[b]{3}{*}{ Stand } & \multirow{2}{*}{\multicolumn{2}{|c|}{ Skips }} & \multicolumn{5}{|c|}{ Types of hills adjoining skips } & \multirow{3}{*}{$\begin{array}{l}\text { Compensa- } \\
\text { tion per } \\
\text { missing hill }\end{array}$} \\
\hline & & & $\mathbf{N}$ & A & B & C & D & \\
\hline & Type & Size & $\begin{array}{l}\text { Normal } \\
\text { hills }\end{array}$ & $\begin{array}{c}\text { Direct } \\
\text { neighbour } \\
\text { in the row }\end{array}$ & $\begin{array}{l}\text { Second } \\
\text { neighbour } \\
\text { in the row }\end{array}$ & $\begin{array}{l}\text { Neighbour } \\
\text { in the } \\
\text { adjacent row }\end{array}$ & $\begin{array}{c}\text { Hills } \\
\text { diagonally } \\
\text { adjacent }\end{array}$ & \\
\hline 1 & (6) & 4 & 100 & $-10.0^{* *}$ & $-17.4^{* *}$ & 0.3 & $-19.4^{* *}$ & $-46.3^{* *}$ \\
\hline 2 & (6) & 4 & 100 & -3.1 & $-14.7^{*}$ & $-14.9 * *$ & $-18.8^{* *}$ & $-51.5^{* *}$ \\
\hline
\end{tabular}

* Significantly different from zero at the $5 \%$ level.

** Significantly different from zero at the $1 \%$ level.

Figures in parenthesis indicate the types of skips in the diagram. 
TABLe 7. EXPERIMENT 4 (1959) WITH SINGLE Cross (WH $\times$ WJ). THE INCREASE IN YIELD OF 'THE HILLS ADJOINING SKIP EXPRESSED AS PERCENTAGE OF THE YIELD OF THE NORMAL HILLS

\begin{tabular}{|c|c|c|c|c|c|c|c|c|}
\hline \multirow[b]{3}{*}{ Stand } & \multirow{2}{*}{\multicolumn{2}{|c|}{ Skips }} & \multicolumn{5}{|c|}{ Types of hills adjoining skips } & \multirow{3}{*}{$\begin{array}{l}\text { Compen- } \\
\text { sation per } \\
\text { missing hills }\end{array}$} \\
\hline & & & $\mathbf{N}$ & A & B & C & D & \\
\hline & Type & Size & $\begin{array}{l}\text { Normal } \\
\text { hills }\end{array}$ & $\begin{array}{c}\text { Direct } \\
\text { neighbour } \\
\text { in the row }\end{array}$ & $\begin{array}{l}\text { Second } \\
\text { neighbour } \\
\text { in the row }\end{array}$ & $\begin{array}{c}\text { Neighbour } \\
\text { in the } \\
\text { adjacent row }\end{array}$ & $\begin{array}{c}\text { Hills } \\
\text { diagonally } \\
\text { adjacent }\end{array}$ & \\
\hline 1 & (1) & 1 & 100 & -3.9 & $-14.0^{* *}$ & $-6.8^{*}$ & -7.0 & $-77.4^{*}$ \\
\hline 1 & (2) & 2 & 100 & 1.0 & 0.3 & 2.4 & 1.4 & 9.0 \\
\hline 2 & (1) & 1 & 100 & $18.9 * *$ & 3.9 & 5.6 & 1.2 & 61.5 \\
\hline 2 & (2) & 2 & 100 & $12.3^{* *}$ & -4.5 & 4.4 & -6.3 & 4.6 \\
\hline
\end{tabular}

* Significantly different from zero at the $5 \%$ level.

** Significantly different from zero at the $1 \%$ level.

Figures in parentheses indicate the types of skips in the diagram.

\section{The experiments of 1960}

In 1960, the results of experiment 1 (table 8) indicated that there was a significant increase in the yield of the direct neighbour and that the compensation for a missing hill was significantly higher than zero in most cases. The compensation was very high and significantly greater than zero at the $1 \%$ level for skips of one missing hill (1) and for skips of two missing hills in two adjacent rows (3). In the second experiment of the same year (table 9) which was just a repetition of experiment 3 of 1959, it was found that there was an increase in the yield of the direct neighbour. Moreover the increase in the yield of the direct neighbour and the mean compensation were significantly higher than zero at the $5 \%$ level for a stand of one plant/hill, and at the $1 \%$ level for a stand of two plants/hill.

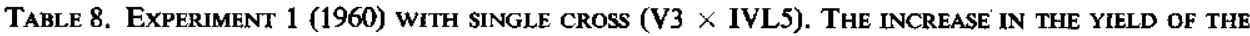
HILLS ADJOINING SKIPS EXPRESSED AS PERCENTAGE OF THE YIELD OF THE NORMAL HILLS

\begin{tabular}{|c|c|c|c|c|c|c|c|c|c|}
\hline \multirow[b]{3}{*}{ Stand } & \multirow{2}{*}{\multicolumn{2}{|c|}{ Skips }} & \multirow{3}{*}{$\begin{array}{c}\text { Nitro- } \\
\text { gen }\end{array}$} & \multicolumn{5}{|c|}{ Types of hills adjoining skips } & \multirow{3}{*}{$\begin{array}{l}\text { Compen- } \\
\text { sation per } \\
\text { missing hill }\end{array}$} \\
\hline & & & & $\mathbf{N}$ & A & B & C & D & \\
\hline & Type & Size & & $\begin{array}{l}\text { Normal } \\
\text { hills }\end{array}$ & $\begin{array}{l}\text { Direct } \\
\text { neighbour } \\
\text { in the row }\end{array}$ & $\begin{array}{l}\text { Second } \\
\text { neighbour } \\
\text { in the row }\end{array}$ & $\begin{array}{l}\text { Neighbour } \\
\text { in the } \\
\text { adjacent row }\end{array}$ & $\begin{array}{c}\text { Hills } \\
\text { diagonally } \\
\text { adjacent }\end{array}$ & \\
\hline 1 & (1) & 1 & 80 & 100 & $11.44 * *$ & 5.30 & 9.48 & 4.84 & $72.0^{* *}$ \\
\hline 1 & (1) & 1 & 120 & 100 & $7.20^{*}$ & -2.49 & 6.65 & 0.45 & $24.0^{* *}$ \\
\hline 1 & (2) & 2 & 80 & 100 & $9.10^{* *}$ & -2.85 & 2.00 & 4.10 & $18.0^{*}$ \\
\hline $\mathrm{I}$ & (2) & 2 & 120 & 100 & $11.00^{* * *}$ & -2.75 & 4.36 & -0.54 & 15.4 \\
\hline 1 & (3) & 2 & 80 & 100 & $8.00^{*}$ & 7.53 & 1.33 & 2.47 & $37.4 * *$ \\
\hline 1 & (3) & 2 & 120 & 100 & 6.60 & 1.43 & -2.16 & 0.26 & 13.7 \\
\hline
\end{tabular}

* Significantly different from zero at the $5 \%$ level.

** Significantly different from zero at the $1 \%$ level.

Figures in parentheses indicate the types of skips in the diagram. 
TABLE 9. EXPERIMENT $3(1960)$ WITH SINGLE CROSS $($ W $103 \times$ V 3 ). THE INCREASE IN THE YIELD OF THE HILLS ADJOINING SKIPS EXPRESSED AS PERCENTAGE OF THE YIELD OF THE NORMAL HILLS

\begin{tabular}{|c|c|c|c|c|c|c|c|c|}
\hline \multirow[b]{3}{*}{ Stand } & \multirow{2}{*}{\multicolumn{2}{|c|}{ Skips }} & \multicolumn{5}{|c|}{ Types of hills adjoining skips } & \multirow{3}{*}{$\begin{array}{l}\text { Compen- } \\
\text { sation per } \\
\text { missing hill }\end{array}$} \\
\hline & & & $\mathbf{N}$ & A & B & $\mathrm{C}$ & D & \\
\hline & Type & Size & $\begin{array}{l}\text { Normal } \\
\text { hills }\end{array}$ & $\begin{array}{c}\text { Direct } \\
\text { neighbour } \\
\text { in the row }\end{array}$ & $\begin{array}{l}\text { Second } \\
\text { neighbour } \\
\text { in the row }\end{array}$ & $\begin{array}{l}\text { Neighbour } \\
\text { in the } \\
\text { adjacent row }\end{array}$ & $\begin{array}{c}\text { Hills } \\
\text { diagonally } \\
\text { adjacent }\end{array}$ & \\
\hline 1 & (6) & 4 & 100 & $7.7^{*}$ & 2.0 & 3.5 & 0.3 & $13.5^{*}$ \\
\hline 2 & (6) & 4 & 100 & $\cdot 11.6 * *$ & -1.2 & 2.9 & 3.8 & $17.2^{* *}$ \\
\hline
\end{tabular}

- Significantly different from zero at the $5 \%$ level.

** Significantly different from zero at the $1 \%$ level.

Figures in parentheses indicate the types of skips in the diagram.

3. The experiments of 1961

a. Experiment I with single cross (W103 $\times \mathrm{CH} 8$ )

Table 10 shows that the compensation per missing hill and the increase in the yield of the direct neighbour over that of the normal hills were consistently and significantly larger than zero at the $1 \%$ level. The increase in the yield of all the neighbours in

TABLe 10. EXPERIMENT I (1961) WITH SINGLe CROSS $($ W103 $\times$ CH8). The INCREASE IN Yield OF the HILLS ADJOINING SKIPS EXPRESSED AS PERCENTAGE OF THE YIELD OF THE NORMAL HILLS

\begin{tabular}{|c|c|c|c|c|c|c|c|c|c|}
\hline \multirow[b]{3}{*}{ Stand } & \multirow{2}{*}{\multicolumn{2}{|c|}{ Skips }} & \multirow{3}{*}{$\begin{array}{l}\text { Nitro- } \\
\text { gen } \\
\text { level }\end{array}$} & \multicolumn{5}{|c|}{ Types of hills adjoining skips } & \multirow{3}{*}{$\begin{array}{l}\text { Compen- } \\
\text { sation per } \\
\text { missing hill }\end{array}$} \\
\hline & & & & $\mathbf{N}$ & A & B & $\mathrm{C}$ & D & \\
\hline & Type & Size & & $\begin{array}{l}\text { Normal } \\
\text { hills }\end{array}$ & $\begin{array}{l}\text { Direct } \\
\text { neighbour } \\
\text { in the row }\end{array}$ & $\begin{array}{l}\text { Second } \\
\text { neighbour } \\
\text { in the row }\end{array}$ & $\begin{array}{c}\text { Neighbour } \\
\text { in the } \\
\text { adjacent row }\end{array}$ & $\begin{array}{c}\text { Hills } \\
\text { diagonally } \\
\text { adjacent }\end{array}$ & \\
\hline 1 & (6) & 4 & 60 & 100 & $24.60^{* *}$ & 2.10 & $9.65^{* *}$ & 2.80 & $39.27^{* *}$ \\
\hline 1 & (6) & 4 & 120 & 100 & $25.35 * *$ & 4.70 & 5.75 & 0.40 & $35.89 * *$ \\
\hline 1 & (5) & 3 & 60 & 100 & $24.88 * *$ & $11.67^{* *}$ & $10.88^{*}$ & $12.38^{* *}$ & $96.99 * *$ \\
\hline 1 & (5) & 3 & 120 & 100 & $26.26^{* *}$ & $13.60^{* *}$ & $16.75^{* *}$ & $15.32^{* *}$ & $111.31^{* *}$ \\
\hline \multicolumn{4}{|c|}{ Mean } & 100 & 25.27 & 8.02 & 8.26 & 7.72 & 70.87 \\
\hline 2 & (6) & 4 & 60 & 100 & $37.35 * *$ & $14.40^{* * *}$ & $10.80^{* *}$ & $14.50^{* *}$ & $77.04^{* *}$ \\
\hline 2 & (6) & 4 & 120 & 100 & $38.35 * *$ & 6.50 & $14.85^{* *}$ & $10.60^{* *}$ & $70.30 * *$ \\
\hline 2 & (5) & 3 & 60 & 100 & $49.04^{* *}$ & $22.94 * *$ & $21.72 * *$ & $22.08^{* *}$ & $187.90^{* *}$ \\
\hline 2 & (5) & 3 & 120 & 100 & $40.60^{* *}$ & $18.90^{* *}$ & $24.35^{* *}$ & $10.36^{* *}$ & $149.05^{* *}$ \\
\hline \multicolumn{4}{|c|}{ Mean } & 100 & 41.34 & 15.68 & 17.93 & 14.38 & 121.09 \\
\hline \multicolumn{4}{|c|}{ General mean } & 100 & 33.30 & 11.85 & 13.10 & 11.05 & 95.69 \\
\hline
\end{tabular}

* Significantly different from zero at the $5 \%$ level.

** Significantly different from zero at the $1 \%$ level.

Figures in parentheses indicate the types of skips in the diagram. 
the treatments containing skips of three missing hills in three rows (5) and a stand of two plants/hill was also significantly higher than zero at the $1 \%$ level. Furthermore, the increase in the grain yield of all the neighbours as well as the compensation per missing hill were generally higher for skips of three missing hills (5) than for skips of four missing hills (6). It was also found that with a stand of two plants/hill the mean increase in the yield of the hills adjoining skips as well as the compensation per missing hill were significantly higher than when a stand of one plant/hill was used.

\section{b. Experiment II with single cross $(\mathrm{W} 103 \times \mathrm{V} 3)$}

The compensation per missing hill and the increase in the grain yield of the direct neighbour in the row were significantly higher than zero at the $1 \%$ level, as shown in table 11. It was also found that in the treatments where a stand of two plants/hill and skips of three missing hills (5) were used, the increase in the yields of all the neighbours was significantly higher than zero at the $1 \%$ level. The compensation of the hills adjoining skips of three missing hills (5) was higher than that of skips of four missing hills (6). There was a certain degree of interaction between stand and nitrogen which can be seen in tables 11,13 and 14 .

\section{c. Experiment III with single cross (V3 $\times$ IVL5)}

Although this experiment was conducted on another field separate from I and II with a different single cross yet, as is obvious from table 12 , the compensation per

TABLE 11. EXPERIMENT II (1961) WITH SINGLE CROSS $($ W103 $\times$ V3). THE INCREASE IN THE YIELD OF THE HILLS ADJOINING SKIPS EXPRESSED AS PERCENTAGE OF THE YIELD OF THE NORMAL HILL

\begin{tabular}{|c|c|c|c|c|c|c|c|c|c|}
\hline \multirow[b]{3}{*}{ Stand } & \multirow{2}{*}{\multicolumn{2}{|c|}{ Skips }} & \multirow{3}{*}{$\begin{array}{l}\text { Nitro- } \\
\text { gen } \\
\text { level }\end{array}$} & \multicolumn{5}{|c|}{ Types of hills adjoining skips } & \multirow{3}{*}{$\begin{array}{l}\text { Compen- } \\
\text { sation per } \\
\text { missing hill }\end{array}$} \\
\hline & & & & \multicolumn{2}{|r|}{ A } & \multicolumn{2}{|c|}{ B $\quad$ C } & D & \\
\hline & Type & Size & & $\begin{array}{c}\text { Normal } \\
\text { hills }\end{array}$ & $\begin{array}{l}\text { Direct } \\
\text { neighbour } \\
\text { in the row }\end{array}$ & $\begin{array}{c}\text { Second } \\
\text { neighbour } \\
\text { in the row }\end{array}$ & $\begin{array}{c}\text { Neighbour } \\
\text { in the } \\
\text { adjacent row }\end{array}$ & $\begin{array}{c}\text { Hills } \\
\text { diagonally } \\
\text { adjacent }\end{array}$ & \\
\hline 1 & (6) & 4 & 60 & 100 & $23.85 * *$ & 2.10 & $8.50 * *$ & 3.60 & $36.00 * *$ \\
\hline 1 & (6) & 4 & 120 & 100 & $30.80 * *$ & 3.40 & $10.55^{* *}$ & 4.80 & $52.00^{* * *}$ \\
\hline 1. & (5) & 3 & 60 & 100 & $30.05^{* *}$ & $10.00^{* *}$ & $12.15^{* *}$ & $16.10^{* *}$ & $109.70^{* *}$ \\
\hline 1 & (5) & 3 & 120 & 100 & $34.00 * *$ & $13.10^{* *}$ & $9.80^{*}$ & $8.40^{*}$ & $107.10^{* *}$ \\
\hline \multicolumn{4}{|c|}{ Mean } & 100 & 29.67 & 7.15 & 10.25 & 8.22 & 76.20 \\
\hline 2 & (6) & 4 & 60 & 100 & $43.10^{* *}$ & $14.40 * *$ & $17.25^{* *}$ & 4.90 & $81.90 * *$ \\
\hline 2 & (6) & 4 & 120 & 100 & $22.25^{* *}$ & 6.90 & $10.75^{* *}$ & 3.70 & $43.60^{* *}$ \\
\hline 2 & (5) & 3 & 60 & 100 & $30.50^{* *}$ & $13.02 * *$ & $16.20 * *$ & $12.10^{* *}$ & $113.20^{* *}$ \\
\hline 2 & (5) & 3 & 120 & 100 & $22.45 * *$ & $12.68 * *$ & $8.30 * *$ & $8.80 * *$ & $89.00^{* *}$ \\
\hline \multicolumn{4}{|c|}{ Mean } & 100 & 29.57 & 11.75 & 12.87 & 7.38 & 81.92 \\
\hline \multicolumn{4}{|c|}{ General mean } & 100 & 29.62 & 9.45 & 11.56 & 7.80 & 79.06 \\
\hline
\end{tabular}

* Significantly different from zero at the $5 \%$ level.

** Significantly different from zero at the $1 \%$ level.

Figures in parenthesis indicate the types of skips in the diagram. 
missing hills and the increase in yield of the direct neighbour and the second neighbour in the row were significantly higher than zero at the $1 \%$ level. In the treatments with a stand of two plants/hill and skips of three missing hills (5) the increase in yield of all neighbours was significantly higher than zero at the $1 \%$ level. Moreover the compensation per missing hill for three missing hills (5) was generally higher than for four missing hills (6). There was no clear difference between the effects of different stands, but it can be seen in table 12 that the increase in the yield of the hills adjoining skips was consistently significantly higher than zero at $1 \%$ level in most cases when a stand of two plants/hill was used. It was also clear that the higher the nitrogen level the higher the increase in the grain yield of hills adjoining skips, regardless of the stand and the type of skips.

\section{d. The effect of the main factors and their interactions}

An analysis of variance was performed for the compensation per missing hill. In the first place each experiment was analysed separately, then experiments I and II were collectively analysed since they were sown on the same field and finally all three experiments were jointly analysed irrespective of differences in the soil. This statistical analysis was carried out with the purpose of gaining an impression about the main effect of skips, stand, nitrogen, hybrids and their interactions. Table 13 shows the compensation per missing hill expressed as percentage of the yield of the normal hills for all the experiments. Table 14 contains the mean squares for the main effects as well

TABle 12. EXPeriment III (1961) WITH SINGLe CROSS $(\mathrm{V} 3 \times$ IVL5). THE INCREASE IN THE YIELd OF THE HILLS ADJOINING SKIPS, EXPRESSED AS PERCENTAGE OF THE YIELD OF THE NORMAL HILLS

\begin{tabular}{|c|c|c|c|c|c|c|c|c|c|}
\hline \multirow{3}{*}{ Stand } & \multirow{2}{*}{\multicolumn{2}{|c|}{ Skips }} & \multirow{3}{*}{$\begin{array}{l}\text { Nitro- } \\
\text { gen } \\
\text { level }\end{array}$} & \multicolumn{5}{|c|}{ Types of hills adjoining skips } & \multirow{3}{*}{$\begin{array}{l}\text { Compen- } \\
\text { sation per } \\
\text { missing hill }\end{array}$} \\
\hline & & & & \multicolumn{2}{|r|}{ A } & B & C & \multirow{2}{*}{$\frac{\mathrm{D}}{\begin{array}{c}\text { Hills } \\
\text { diagonally } \\
\text { adjacent }\end{array}}$} & \\
\hline & Type & Size & & $\begin{array}{c}\text { Normal } \\
\text { hills }\end{array}$ & $\begin{array}{l}\text { Direct } \\
\text { neighbour } \\
\text { in the row }\end{array}$ & $\begin{array}{c}\text { Second } \\
\text { neighbour } \\
\text { in the row }\end{array}$ & $\begin{array}{c}\text { Neighbour } \\
\text { in the } \\
\text { adjacent row }\end{array}$ & & \\
\hline 1 & (6) & 4 & 60 & 100 & $25.00 * *$ & $15.20^{* *}$ & $8.95 *$ & 3.90 & $53.20 * *$ \\
\hline 1 & (6) & 4 & 120 & 100 & $30.08 * *$ & $17.30 * *$ & $13.10^{* *}$ & $8.50^{*}$ & $69.00^{* *}$ \\
\hline 1 & (5) & 3 & 60 & 100 & $33.15^{* *}$ & $13.50 * *$ & 10.18 & $13.80^{*}$ & $119.50^{* *}$ \\
\hline 1 & (5) & 3 & 120 & 100 & $47.60 * *$ & $23.90^{* *}$ & 10.00 & $11.65^{* *}$ & $165.20 * *$ \\
\hline \multicolumn{4}{|c|}{ Mean } & 100 & 33.96 & 17.48 & 10.56 & 9.46 & 101.72 \\
\hline 2 & (6) & 4 & 60 & 100 & $24.35^{* *}$ & $12.40 * *$ & $7.10^{* *}$ & $7.90^{*}$ & $51.60 * *$ \\
\hline 2 & (6) & 4 & 120 & 100 & $36.50 * *$ & $11.50 * *$ & $15.70 * *$ & $12.50 * *$ & $76.30^{* *}$ \\
\hline 2 & (5) & 3 & 60 & 100 & $31.00 * *$ & $16.85^{* *}$ & $12.90 * *$ & $13.50^{* *}$ & $122.10^{* *}$ \\
\hline 2 & (5) & 3 & 120 & 100 & $33.45^{* *}$ & $13.90^{* *}$ & $12.75 * *$ & $17.30 * *$ & $126.10^{* *}$ \\
\hline \multicolumn{4}{|c|}{ Mean } & 100 & 31.32 & 13.66 & 12.09 & 12.80 & 94.25 \\
\hline \multicolumn{4}{|c|}{ General mean } & 100 & 32.64 & 15.57 & 11.33 & 11.13 & 97.87 \\
\hline
\end{tabular}

* Significantly different from zero at the $5 \%$ level.

** Significantly different from zero at the $1 \%$ level.

Figures in parentheses indicate the types of skips in the diagram. 


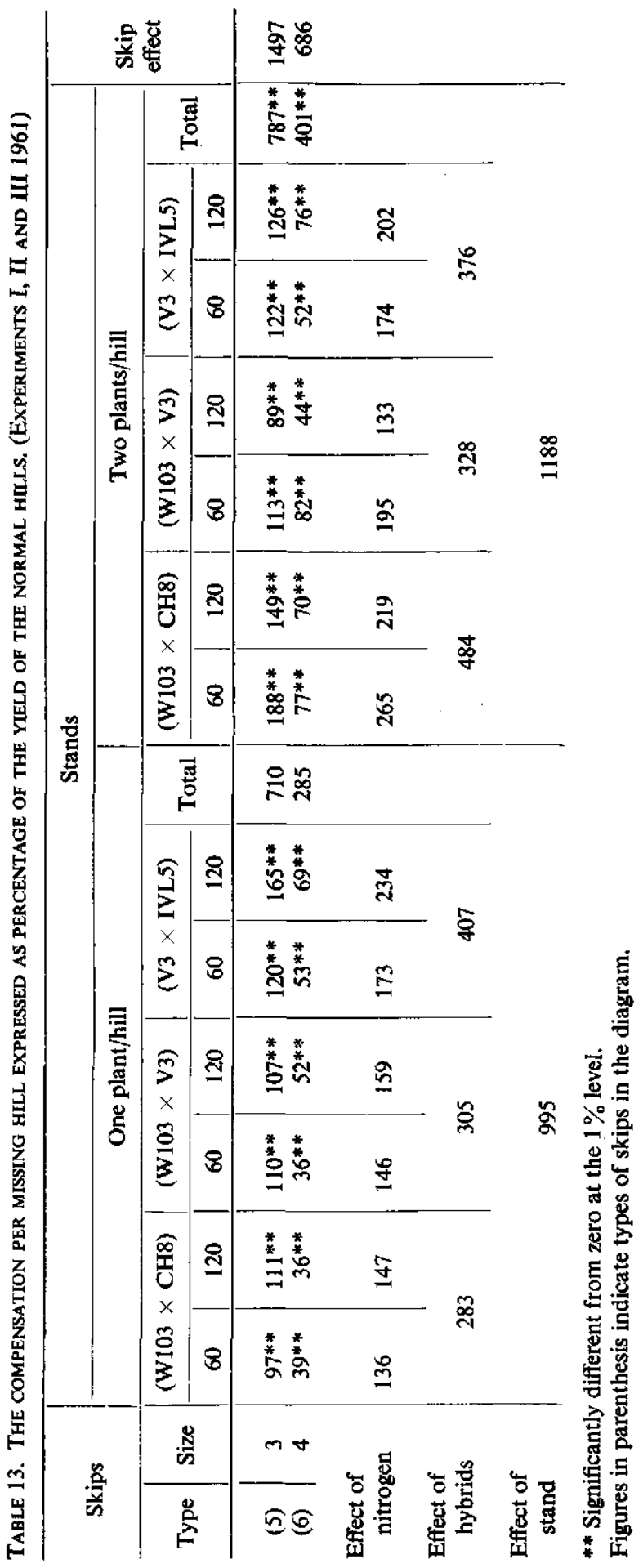


TABle 14. MEAN SQUaRes For the MAIN FACTORS AND THER INTERACTIONS FOR THE COMPENSATION PER MISSING HILL IN THE EXPERIMENTS OF 1961

\begin{tabular}{l|r|r|r|r|r}
\hline \multicolumn{1}{c|}{ Source of variation } & $\begin{array}{c}\text { I } \\
\text { (W103 } \times \text { CH8) }\end{array}$ & $\begin{array}{c}\text { II } \\
(\text { W103 } \times \text { V3) }\end{array}$ & $\begin{array}{c}\text { III } \\
(\text { V3 } \times \text { IVL5) }\end{array}$ & I \& II & I, II, III \\
\hline Skips & 13041.00 & 5253.00 & 10011.15 & $17424.00^{* *}$ & $27405.10^{* *}$ \\
Stand & 5050.00 & 66.00 & 120.15 & $3136.00^{*}$ & $1552.00^{*}$ \\
Nitrogen & 153.00 & 300.00 & 990.15 & 441.00 & 1.04 \\
Hybrids & & & & 1122.25 & 848.15 \\
Skips $\times$ Stand & 276.00 & 338.11 & 231.13 & 1.00 & 63.38 \\
Skips $\times$ Nitrogen & 28.10 & 3.15 & 10.12 & 25.00 & 5.04 \\
Skips $\times$ Hybrids & & & & 870.25 & 450.18 \\
Stand $\times$ Nitrogen & 406.10 & 703.10 & 136.12 & 1089.00 & $1134.37^{*}$ \\
Stand $\times$ Hybrids & & & & $1980.25^{*}$ & $1842.22^{* *}$ \\
Nitrogen $\times$ Hybrids & & & & 12.25 & 721.22 \\
Error & 431.00 & 149.60 & 300.08 & 243.80 & 200.95
\end{tabular}

* Significant at the $5 \%$ level.

** Significant at the $1 \%$ level.

as their interactions. It was found that the effect of skips was high in all the experiments and that it differed much between the different hybrids. It was also found that when the experiments were taken collectively the skips effect was significant at the $1 \%$ level. The stand effect was very high in experiment $\mathbf{I}$, and when the experiments were considered collectively it was significant at the $5 \%$ level. There was no significant effect of nitrogen on the compensation per missing hill, although when experiment III was considered separately the remarked effect of nitrogen was apparent. Despite the hybrids effect was rather high, yet it did not reach the level of statistical significance. The single crosses (W103 $\times \mathrm{CH} 8)$ and (W103 $\times \mathrm{V} 3$ ) show a certain degree of interaction between stand and nitrogen which was rather high in the case of (W103 $\times$ V3) and it was significant at the $5 \%$ level when the three experiments were taken collectively. The interaction between stand and hybrid was significant at the $5 \%$ level for I and II and at the $1 \%$ level for the three experiments collectively.

\section{e. The effect of years}

Single cross (W103 $\times$ V3) was sown for three successive years (experiments IfI 1959, III 1960 and II 1961) with a stand of one and two plants/hill and skips of four missing hills in two rows (6). Table 15 shows the effect of stand on the yield of the hills located around a skip in the three seasons.

In 1960 the increase in the yield of the direct neighbour and the compensation per missing hill was significantly higher than zero at the $5 \%$ and the $1 \%$ level for a stand of one plant/hill and two plants/hill respectively. In 1961 the increase in the yield of the direct neighbour and the neighbour in the adjacent row, as well as the compensation per missing hill were significantly higher than zero at the $1 \%$ level. It was also clear that the increase in the yield of the direct neighbour as well as the compensation were always higher for a stand of two plants/hill than a stand of one plant/hill and that there was a wide difference between the three seasons.

On the other hand in 1959, there was a decrease in the yield of all the neighbours 
TABje 15. Effect of Years AND Climatic conditions. Single Cross (W103 $\times$ V3). The INCREASE IN YIELD OF THE HILLS ADJOINING SKIPS IN PERCENTAGE OF THE YIELD OF NORMAL HILLS IN THE YEARS 1959, 1960 AND 1961

\begin{tabular}{|c|c|c|c|c|c|c|c|c|c|}
\hline \multirow[b]{3}{*}{ Season } & \multirow{3}{*}{ Stand } & \multirow{2}{*}{\multicolumn{2}{|c|}{ Skips }} & \multicolumn{5}{|c|}{ Types of hills adjoining skips } & \multirow{3}{*}{$\begin{array}{l}\text { Compen- } \\
\text { sation per } \\
\text { missing hills }\end{array}$} \\
\hline & & & & $\mathbf{N}$ & A & $\mathbf{B}$ & C & $\mathbf{D}$ & \\
\hline & & Type & Size & $\begin{array}{c}\text { Normal } \\
\text { hills }\end{array}$ & $\begin{array}{c}\text { Direct } \\
\text { neighbour } \\
\text { in the row }\end{array}$ & $\begin{array}{c}\text { Second } \\
\text { neighbour } \\
\text { in the row }\end{array}$ & $\begin{array}{c}\text { Neighbour } \\
\text { in the } \\
\text { adjacent row }\end{array}$ & $\begin{array}{c}\text { Hills } \\
\text { diagonally } \\
\text { adjacent }\end{array}$ & \\
\hline 1959 & $\begin{array}{l}1 \\
2\end{array}$ & $\begin{array}{l}\text { (6) } \\
(6)\end{array}$ & $\begin{array}{l}4 \\
4\end{array}$ & $\begin{array}{l}100 \\
100\end{array}$ & $\begin{array}{l}-10.00^{* *} \\
-3.10\end{array}$ & $\begin{array}{l}-17.40^{* *} \\
-14.70^{* *}\end{array}$ & $\begin{array}{c}0.32 \\
-14.90^{* *}\end{array}$ & $\begin{array}{l}-19.40^{* *} \\
-18.80^{* *}\end{array}$ & $\begin{array}{l}-46.30^{* *} \\
-51.50^{* *}\end{array}$ \\
\hline 1960 & $\begin{array}{l}1 \\
2\end{array}$ & $\begin{array}{l}(6) \\
(6)\end{array}$ & $\begin{array}{l}4 \\
4\end{array}$ & $\begin{array}{l}100 \\
100\end{array}$ & $\begin{array}{c}7.70^{*} \\
11.60^{* *}\end{array}$ & $\begin{array}{r}2.00 \\
-1.20\end{array}$ & $\begin{array}{l}3.50 \\
2.95\end{array}$ & $\begin{array}{l}0.30 \\
3.80\end{array}$ & $\begin{array}{l}13.50^{*} \\
17.20^{* *}\end{array}$ \\
\hline 1961 & $\begin{array}{l}1 \\
2\end{array}$ & $\begin{array}{l}\text { (6) } \\
\text { (6) }\end{array}$ & $\begin{array}{l}4 \\
4\end{array}$ & $\begin{array}{l}100 \\
100\end{array}$ & $\begin{array}{l}23.85^{* *} \\
43.10^{* *}\end{array}$ & $\begin{array}{c}2.10 \\
14.40^{*}\end{array}$ & $\begin{array}{r}8.50^{* *} \\
17.25^{* *}\end{array}$ & $\begin{array}{l}3.60 \\
4.90\end{array}$ & $\begin{array}{l}36.00^{* * *} \\
81.90^{* * *}\end{array}$ \\
\hline
\end{tabular}

* Significantly different from zero at the $5 \%$ level.

** Significantly different from zero at the $1 \%$ level.

Figures in parentheses indicate types of skips in the diagram.

of a skip as well as the compensation per missing hill. The decrease was in most cases significantly less than zero at the $1 \%$ level. This decrease can be attributed to the abnormal weather conditions of 1959 . In that year the effect of drought was very severe especially on wide skips of type (6), and the hills adjoining the skips suffered from lack of water and some of them actually died earlier than those far from the skips. The yield of those hills was considerably less than that of the normal hills. This seems to be in agreement with the findings of RoBins et al. (1953) and DENMEAD et al. (1960) who reported that the moisture stress prior to silking, at silking and after silking reduced the grain yield by $25 \%, 50 \%$ and $21 \%$ respectively.

\section{f. Summary of the results of 1961}

The results of 1961 can be summarized in the following points which were valid in the three experiments.

1. The compensation per missing hill was significantly higher than zero at the $1 \%$ level.

2. The compensation per missing hill for skips of 3 missing hills in three rows (5) was always higher than for skips of four missing hills in two rows (6).

3. The increase in the yield of the direct neighbour was consistently significantly higher than zero at the $1 \%$ level.

4. The increase in the yield of all the neighbours of skips was consistently higher than zero at the $1 \%$ level for treatments with a stand of two plants/hill and skips of three missing hills in three rows (5). 
TABLE 16. THE EFFECT OF ORIENTATION EXPRESSED AS PERCENTAGE OF THE YIELD OF THE HILLS SITUATED TO THE SOUTH OR TO THE EAST OF THE SKIPS

\begin{tabular}{|c|c|c|c|c|c|c|c|c|c|}
\hline \multirow[b]{2}{*}{ Stand } & \multicolumn{2}{|c|}{ Skips } & \multirow{2}{*}{$\begin{array}{l}\text { Nitrogen } \\
\text { Kilogr. }\end{array}$} & \multicolumn{3}{|c|}{ North/South } & \multicolumn{3}{|c|}{ West/East } \\
\hline & Type & Size & & $\begin{array}{l}\text { (W103 } \\
\times \text { CH8) }\end{array}$ & $\begin{array}{r}(\mathrm{W} 103 \\
\times \mathrm{V} 3)\end{array}$ & $\begin{array}{l}\text { (V3 } \\
\times \text { IVL5) }\end{array}$ & $\begin{array}{l}\text { (W103 } \\
\times \text { CH8) }\end{array}$ & $\begin{array}{r}\text { (W103 } \\
\times \text { V3) }\end{array}$ & $\begin{aligned} & \text { (V3 } \\
\times & \text { IVL5) }\end{aligned}$ \\
\hline 1 & (6) & 4 & 60 & 105 & 113 & 98 & 102 & 109 & 110 \\
\hline 1 & (6) & 4 & 120 & 110 & 107 & 111 & 104 & 101 & 100 \\
\hline 1 & (5) & 3 & 60 & 102 & 108 & 104 & 113 & 93 & 110 \\
\hline 1 & (5) & 3 & 120 & 112 & 107 & 108 & 91 & 108 & 105 \\
\hline 2 & (6) & 4 & 60 & $120^{* *}$ & 103 & $117^{*}$ & $112^{*}$ & $115^{* *}$ & 104 \\
\hline 2 & (6) & 4 & 120 & 112 & $111^{* *}$ & 110 & 110 & $113^{*}$ & 105 \\
\hline 2 & (5) & 3 & 60 & 107 & 108 & 108 & 102 & 106 & 102 \\
\hline 2 & (5) & 3 & 120 & 104 & 104 & 120 & 112 & 103 & 104 \\
\hline \multicolumn{4}{|c|}{ Mean } & $109.00^{* *}$ & $107.60^{* *}$ & $109.50^{*}$ & 105.75 & 106.00 & $105.00^{* *}$ \\
\hline
\end{tabular}

* Significantly greater than 100 at the $5 \%$ level.

** Significantly greater than 100 at the $1 \%$ level.

Figures in parentheses indicate the types of skips in the diagram.

\section{$B$. The effect of orientation}

It is quite obvious that the position of a neighbouring hill with respect to a skip would have a considerable effect on the yield. As far as sunlight is concerned a neighbouring hill situated at the north of a skip, and which therefore has no adjoining hills at the south is undoubtedly better off than a hill situated at the south of the skip, which is consequently bordered at the south with neighbouring hills. Similar contrasts as concerns morning and afternoon sun occur between the hills situated at the west side and those situated at the east side of a skip. We wondered whether such differences in the position of the hills also manifest themselves in the extent to which they compensate for the loss in total yield due to the presence of skips. The figures given in table 16 shed some light on this question. The effect of the orientation of the hills around a skip on the grain yield is expressed as a percentage of the hills situated to the south or to the east. The percentages in the table were consistently higher than 100 in all the treatments with the exception of three which were less than 100 . The statistical analysis showed that the percentages were significantly higher than 100 in some cases. The mean effect of orientation on the direct neighbour in the row was significantly higher than 100 at the $1 \%$ level for all the hybrids. It was also found that there was an increase of about 7.6 to $9.5 \%$ in the yield of the hills situated to the north over the yield of the hills situated to the south regardless of the type of the neighbour. The factors studied as well as the interactions between them did not show any significant effect on the orientation of the hills around skips.

\section{DISCUSSION}

\section{A. Compensation}

In the present study it was found that there was an increase in the yield of the hills directly adjacent to skips in the row. This is in agreement with the work done by a 
large number of investigators working with different crops. Among these investigators are Mayer Gmelin (1910), Roemer (1930), Pedersen (1933) and Schlösser et al. (1961) working with sugar beet; FITCH and BENNET (1910), STEWART (1919 and 1921) and LiVERMORE (1931) working with potatoes; BREWBAKER and IMMER (1927), KIESSELBACH (1923) and GIESBRECHT (1961) working with maize.

This did not only hold for the direct neighbour in the row (A) but also for the yield of the second neighbour in the row (B), for the yield of the neighbour in the adjacent row (C) and for the yield of the hills diagonally adjacent to the skip (D). It was also confirmed by PEDERSEN (1933) working with sugar beet, and POPE (1947) and GutiérREZ et al. (1954) working with cotton who found that there was an increase in the yield of the direct neighbour and a lateral compensation by the hills adjoining the skips in the adjacent rows. However, the increase in the yield of the direct neighbour (A) was considerably higher than the yield of the other neighbours. It was also shown in table 5 that the direct neighbour (A) may develop so strongly that it affects the yield of the second neighbour (B) to such a large extent that it was sometimes less than the yield of the normal hills.

Fitch and Bennet (1910), Stewart (1919) and (1921) and Livermore (1927) used the second neighbour in the row $(B)$ and the neighbour in the adjacent row $(C)$ as check in comparison with the direct neighbour (A) to calculate the compensation for the loss in total yield. Since it was found in this study that there was an increase in the yield of those types and that it was sometimes negative (1959), then it would seem that the methods used by these investigators mentioned above were wrong. The comparison in their work was not fair since they were comparing the direct neighbour (A) with types which have also been affected by the skip. In the present study this point was taken into consideration and efforts have been made to compare the neighbours of a skip with hills which have the least chance to be affected. Therefore the normal hills were taken at least two hills far from the skip in the row and one row further from the skip as shown in the diagram page 6 .

It was also found that a skip is not always an advantage to its neighbours, it may as well be a disadvantage under certain conditions, as for instance in the summer of 1959 which was abnormally dry.

However, the present study showed that the effect of skips was highly influenced by many factors. Among these factors are the size and shape of the skips, stand, nitrogen level, nature of the hybrids and seasonal and climatic conditions.

\section{The effect of size and shape of skips}

In the present study it was found that the effect of skips was significant at the $1 \%$ level of significance as shown in table 14. Referring to tables 4 and 8 , it was found that the larger the size of the skips the smaller the magnitude of compensation for the loss in the total yield. STEwART (1921) found that a skip of one missing hill was compensated for more than that of three missing hills. PEDersen (1933) found that the loss in the total yield increased by increasing the size of the skip. POPE (1947) and GuTiéRREZ et al. (1954) found that the larger the size of the skip the larger the loss in the total yield.

Moreover the shape of the skips is also very important, since it was found that skips with the same number of missing hills but which differ in their shape were not com- 
pensated for in the same magnitude. Tables 4 and 8 , show the difference in the compensation for the loss in yield between the types of skips (2) against (3) and (4) against (5), where the hills were located either in one row or in a number of adjacent rows. It was found that when the missing hills of a multiple-hill skip were located in one row or a number of adjacent rows, the compensation for the loss in the total yield was higher for the types (3) and (5) than for the types (2) and (4). Furthermore, it was observed that the direct neighbour (A) mostly compensated higher for the loss in yield than the other types of neighbours. Thus the larger the number of hills of this type the higher the compensation for the loss in yield. For example, a skip of type (2) has only two (A) neighbours, while a skip of type (3) has four (A) neighbours compensating for the same number of missing hills. On the other hand, a skip of type (4) has two (A) neighbours compensating for three missing hills, while a skip of type (5) has six (A) neighbours compensating for the same number of missing hills. Moreover, for skips of types (5) and (6) used in 1961, a skip of type (5) has six (A) neighbours compensating for three missing hills while a skip of type (6) has four (A) neighbours compensating for four missing hills. The difference in the compensation for the loss in yield due to these types of skips may be due to the fact that skips of types (2), (4) and (6) were wide and open for sunlight and the penetration of the wind which accelerates the conditions of drought in the soil within the skip and which sometimes extended further in a dry season like that of 1959. On the other hand the shape of a skip of type (3) or (5) which is narrow and elongated minimizes the influence of the weather conditions on the hills around the skip.

\section{The effect of stand}

Table 14 shows that the effect of stand was significant at the $5 \%$ level. This means that stand has a great influence on the rate of compensation for the loss in yield due to missing hills. The result is in agreement with the work of HUELSEN (1943), who found that when the stands of 2,3 and 4 plants/hill were alternated with skips, the reduction in yield was $31.8,26.9$ and $22.6 \%$ respectively. This means that the denser the stand the higher the rate of compensation for the loss in the total yield.

There was also a significant interaction between stand and hybrids. This means that the effect of stand varies from one hybrid to an other. Also there was a significant interaction between stand and nitrogen; it was clear for the single cross (W103 $\times \mathrm{V} 3$ ) and small for the other hybrids. Table 10 shows that for the single cross (W103 $\times \mathrm{CH} 8$ ) the compensation per missing hill, as well as the increase in the yield of the hills adjoining skips for a stand of two plants/hill, was considerably higher than one plant/ hill. The interactions were negligible. It seems that this hybrid is tolerant to dense planting. MCVICKAR and SHEAR (1946) indicate that hybrids respond to thick planting better than open pollinated varieties and that hybrids differ with respect to their response to population levels. LANG et al. (1956) reported that the singie cross (Hy2 $\times \mathrm{Ch} 7$ ), proved highly tolerant to high rates of planting and made its highest yield at 20,000 plants per acre, while single cross (WF9 $\times$ C103), was less tolerant and made its highest yield at 12,000 plants per acre. STINSON et al. (1960) and (1961) found that there was a differential response of maize hybrids to shade and that hybrids which were tolerant to shade were also tolerant to thick planting. However, it seems that for (W103 $\times$ CH8) the distances between hills were not sufficiently large for the hills 
to attain their maximum productivity when a stand of two plants/hill was used. Therefore, when the hills were given more space in the form of a skip, they were able to exhibit their properties by increasing their yields. Moreover (W103 $\times \mathrm{CH} 8$ ) is a strong single cross and the high increase in the yield of the neighbours of the skips for a dense stand as comparable with that for a thin stand, may be related to the increase in competition between hills and plants when a dense stand was used.

Table 12 shows that for (V3 $\times$ IVL5) the compensation per missing hill was higher for a stand of one plant/hill than two plants/hill. Single cross $(V 3 \times$ IVL5) is a typical flint-dent which is characterised by the production of many strong earbearing tillers when a stand of one plant/hill was used. When the stand was one plant/hill and the plants were adjoining skips the tillers became strong and produced ears. Therefore a high increase in the yield of the neighbours of the skips was observed and it was found that it was equal or sometimes higher than that for a stand of two plants/hill. This is in agreement with the work of DUNGAN (1931) and ROSENQUIST (1941) working with maize, and BARTEL et al. (1955) working with sorghums. They found that tillers in addition to producing grain themselves may contribute to grain formation on the main stalk under some conditions. Thus it would seem that tillers have played a part in the compensation for the loss in yield of (V3 $\times$ IVL5) with a stand of one plant/hill.

\section{The effect of nitrogen}

The effect of nitrogen was high on (V3 $\times$ IVL5); as it showed response to higher levels of nitrogen, it was somewhat lower on (W103 $\times$ V3) and very low on (W103 $\times$ CH8). There was a high, although non-significant, interaction between stand and nitrogen on the compensation per missing hill for $(\mathrm{W} 103 \times \mathrm{V} 3)$. When a stand of two plants/hill and a low level of nitrogen were used, a high increase in the yield of the hill adjoining skips was found, while for a stand of one plant/hill there was a high response for high nitrogen levels. This may be attributed to the increased competition for nitrogen between hills when a dense stand was used. Moreover the interaction between stand and nitrogen was significant at the 5\% level when the three hybrids were considered collectively regardless of the soil differences. When $(\mathrm{W} 103 \times \mathrm{CH} 8)$ and (W103 $\times$ V3) were taken collectively the interaction was high but not significant and this may be related to the small number of degrees of freedom for the error variance in case the two hybrids were taken collectively or separately.

Nevertheless the data presented show that, in our trials, nitrogen has a small effect on the influence of skips on their neighbours.

\section{The effect of hybrids}

Referring to table 14, it was shown that the effect of hybrids was high, although not significant for $(\mathrm{W103} \times \mathrm{CH} 8)$ and $(\mathrm{W} 103 \times \mathrm{V} 3)$ which were grown on the same field.

Single cross $($ W103 $\times$ V3) a short hybrid, showed a low effect on the influence of missing hills and a high although non-significant interaction between stand and nitrogen. This interaction may be related to the increased competition for nitrogen and sunlight when a stand of two plants/hill and a low nitrogen level were used, while the competition was reduced considerably for a high nitrogen level (table 11).

The data presented in table 10 shows that $(\mathrm{W} 103 \times \mathrm{CH} 8)$ has a higher effect on the 
yield of the hills adjoining skips with a stand of two plants/hill than with a stand of one plant/hill. This may be related to the increased competition when a dense stand was used. This hybrid may be tolerant to dense planting but when a stand of two plants/hill was used the plants were not able to exhibit this property because the distances between rows and between hills $(70 \times 35 \mathrm{~cm})$ were not sufficient. Therefore when space was available in the form of skips, the hills adjoining them showed their property by a considerable increase in their yield over that of the normal hills.

Single cross $(V 3 \times$ IVL5) is a typical flint-dent characterized by the production of many tillers, especially when a stand of one plant/hill is used. Therefore when a stand of one plant/hill was used, a high increase in the yield of the hills adjoining the skips was obtained because these plants developed many strong tillers and many of them developed ears. It was also found that there was a high response to high levels of nitrogen, which may be related to the hybrid itself or to the type of soil on which it was grown.

The analysis of variance (table 14) for the compensation per missing hill indicated that the three hybrids behaved differently for the different stands and nitrogen levels. This was indicated by the highly significant stand $\times$ hybrid interaction and the significant interaction between stand $\times$ nitrogen.

\section{The effect of years and climatic conditions}

The data presented in table 3 show the variation in the climatic conditions during the growing seasons 1959,1960 , and 1961. The summer of 1959 was characterized by relatively high temperature, excess of sunlight and lack of rainfall especially during May, June, August and September. The growing season of 1960 was a relatively normal one with the exception of April and May when the rainfall was insufficient, while in 1961 it was a favourable season for maize growing in this part of the Netherlands.

Referring to table 15, the data present the results of an experiment carried out through 1959, 1960 and 1961, using single-cross (W103 $\times$ V3) with a stand of one plant and two plants per hill and skips of type (6) in the diagram. The data of 1959 showed that the increase in the yield of all the types of hills adjoining the skips and the compensation per missing hill were significantly less than zero at the $1 \%$ level. This is in connection with the lack of the water supply available for the plants especially in the vegetative stages of growth (May and June) and during the time of ripening (September). Thus the ears as well as the kernels were not fully developed because the plants were not able to supply them with an ample quantity of water and food. Moreover the decrease in yield was more clear when a stand of two plants/hill was used. Therefore it would be safe to conclude that lack of moisture and excess of sunlight have reduced the competition between the hills adjoining skips in so far as competition is measured by an increase in yield. However, this is confirmed with the findings of RoBINs et al. (1953) and DENMEAD et al. (1960) who found that the moisture stress prior to silking, at silking and after silking reduced the yield of maize by $25 \%$, $50 \%$ and $21 \%$ respectively.

In 1960 and 1961 the rainfall was sufficient, therefore the situation was reversed and there was an increase in the yield of the hills adjoining skips over that of the normal 
hill. The increase in yield was also generally higher in 1961 than in 1960 and it was always higher for a stand of two plants/hill than for a stand of one plant/hill.

However, LIVERMORE (1927) and SCHLöSSER et al. (1961) found that season as well as changes in the climatic conditions have a great influence on the effect of skips.

\section{B. The effect of orientation}

From the figures given in table 16 we derived the conclusion that the orientation had an effect on the compensation for the loss in total yield due to skips. The effect of orientation was always in favour of hills situated to the north or to the west of the skip. The yield of the hills situated to the north showed an increase which ranged from 7.6-9.5\% over the yield of the hills situated to the south, while the increase was $5.0-6.0 \%$ in the yield of the hills situated to the west over those situated to the east. The mean effect of the orientation was high and significantly larger than 100 in many cases when skips of type (6) and a stand of two plants/hill were used. On the other hand the effect of the main factors studied and their interactions were non-significant. Consequently one can attribute the effect of orientation mainly to weather conditions and partly to other factors such as skip size, skip shape and type of stand which tend to make the effect of weather conditions more prominent.

\section{The use of adjustment formulae to correct plot yields for missing hills}

Various methods have been used by maize breeders to correct for the effect of missing hills. One of the commonest practices is over-planting, followed by thinning to the desired stand after emergence. Missing hills may however still occur by insects, diseases or mechanical damage during cultivation etc. Another method is to provide the necessary competition to the neighbours of a skip by "spiking in" a distinctive variety of maize or even another species like sunflower. Transplanting maize plants grown in pots, was also used in the 2 or 3 leaf-stage but the act of "spiking in" or transplanting may itself disturb the neighbouring hills. Moreover the competition of the substitute plants may also vary considerably from that of the original hills.

Several methods have been used in adjusting the yield of maize plots containing missing hills. The most popular adjustment formula which was recommended by the F.A.O. and U.S.D.A. is:

where:

$$
\mathrm{CW}=\mathrm{FW}+\frac{\mathrm{FW}}{\mathrm{N}} \times 0.7 \times \mathrm{n}
$$

$$
\begin{aligned}
\text { CW } & =\text { Corrected weight of plot } \\
\text { FW } & =\text { Field weight of plot } \\
\mathbf{N} & =\text { No of hills at harvest } \\
\mathbf{n} & =\text { No of missing hills. }
\end{aligned}
$$

This formula was suggested on the basis that for every missing hill only 0.7 of the average yield of the remaining hills was lost and the other 0.3 was compensated for by the neighbours of the skip. LAUBSCHER (1955) reported that the origin of this formula is unknown. However, from the results of the presents study, it seems that the corrections which can be obtained by using such a formula may lead to an increase in the experimental error since: 
1. The correction is based on the average yield of the remaining hills and this is higher than that of the full stand because of the increase in the yield of the hills adjoining skips.

2. It takes only into account the number of missing hills (not more than 5) regardless of the size and shape of the skips which play a big part in the compensation for the loss in yield.

3. The rate of the compensation (0.3) for the loss in yield is assumed to be constant for varieties, stands, seasons, etc.

The covariance analysis has also been used in some cases for adjusting the yield of plots containing missing hills. Although the adjustment by means of an analysis of covariance decreases the experimental error, yet it is time consuming and difficult in the case of complex designs like the lattice. Moreover it seems that the two conditions on which the covariance analysis is based are in conflict with the biological point of view, because;

a. The regression coefficient is considered the same for all entries.

b. The regression is taken as linear and in fact the relation between the number of plants and yield is not linear since there is an optimum number of plants per unit area at which the yield begins to decrease as reported by LANG et al. (1956).

Furthermore, when using the analysis of covariance we only take into account the number of missing hills regardless of the variety, the size and shape of skips, the type of stand, the nitrogen level and the seasonș. On the other hand the covariance adjustments always work on average conditions and thus are never entirely accurate.

Several investigators working with different crops used different types of formulae for adjusting the yield of plots containing missing hills.

KÜPPER (1927), VON SENGBUSCH (1928) and HENRICH (1930) used the following type of formulae for adjusting the yield of sugar beet in plots containing missing hills:

$$
\mathrm{AW}=\mathrm{FW} \times \frac{\mathrm{N}+\frac{\mathrm{M}}{2}}{\mathrm{~N}}
$$

where: $\mathrm{AW}=$ Adjusted weight

$\mathrm{FW}=$ Field weight

$\mathrm{N}=$ Number of plants at harvest

$\mathrm{M}=$ Number of missing plants

$2=$ The reciprocal value of the part of the skip which was not used by the neighbours, assuming that the hills adjoining the skip have utilized only $50 \%$ of the skip. However, this value $(50 \%)$ was generally accepted by ROEMER (1930) for sugar beet. On the other hand PeDersen (1933) found that this value was lower than that found in the Danish experiments.

ROEMER (1930) pointed out that this method of correction is a compromise between two facts:

1. The harvested yield which is lower than that with full stand. 
2. The adjusted yield which was calculated by dividing the harvested yield by the number of plants at harvest and multiplying this by the number of plants which should have been found in the plot.

He added that the latter is a high estimate for the average yield since the yield of the hills adjoining the skip has been increased. Therefore the right way is to discard the yield of all the hills affected by the skip, to take the average of those which have not been affected and multiply this by the number of hills which should have been found in the plot. This method was also recommended by ScHLösser et al. (1961).

However, the writer is of the opinion that, in addition to the remarks of ROEMER, it should be stated that the formula used by KüPPER (1927), vON SENGBUSCH (1928) and HeNRICH is of limited use, since it was based on empirical basis. Moreover, no attention has been paid to the size and shape of the skips, the varieties used, fertility and seasons.

SCHLÖsSER et al. (1961) compared several adjustment methods and found that the statistical inference was highly influenced by the adjusting method. They also found that in some cases $12-20 \%$ of the selected material in a selection programme would have not been chosen if adjustment had not been carried out.

POPE (1947) and GUTIÉRREZ et al. (1954) working with cotton used another formula for adjusting the yield of single-row plots when the size of the skip exceeds three feet. But even here the formula was not sufficiently reliable since according to POPE the corrections obtained in some cases were either too high or too low. Also they did not take into account the shape of the skips, the differences between varieties, stand, fertility, seasons or climatic conditions and other factors that may influence the compensation for the loss in yield due to skips.

\section{SUMMARY}

Experiments were carried out with maize during the years 1959, 1960, and 1961 with the purpose of studying the effect of skips on the adjoining hills and some factors which may have some influence on this effect. Among the factors studied are; the size and shape of skips, the type of stand, the amount of nitrogen applied, the hybrids used and the climatic conditions during the years considered.

Under the conditions of the Netherlands, the following results were obtained.

1. There was an increase in the yield of the hills adjoining a skip in the same row and in the adjacent rows and the effect of a skip on the direct neighbour in the row (A) was very high.

2. Although the shape of the skips was never mentioned in literature, the present study has clearly demonstrated that the size of a skip is not the only factor to be taken into account, but the shape of the skip has to be considered as well. The effect of skips was significant at the $1 \%$ level of significance.

3. Stand had a significant effect on the influence of skips on their neighbours and it differed significantly from one hybrid to the other as judged from the highly significant interaction between stand and hybrids.

4. Hybrids differed widely in their response to skips, stand and nitrogen levels. 
5. There was an apparent effect of years and climatic conditions on the rate of compensation for the loss in total yield.

6. Nitrogen played a minor effect among the factors studied and it reacted differently with different stands.

7. The orientation of the hills around a skip played a big part in the compensation for the loss in yield, since the hills located to the north have compensated $7.6-9.5 \%$ more than those located to the south and hills located to the west compensated $5.0-6.0 \%$ more than those situated to the east.

\section{CONCLUSIONS}

From the results of the present study and the review of the adjustment methods mentioned before the following conclusions can be drawn:

1. The effect of skips is not constant. On the contrary it is influenced by many factors among which the size and shape of skips, the type of stand used, the hybrids and years and climatic conditions play a major role.

2. As a consequence of 1 the use of adjustment formulae based on the over simplified concept of a constant adjustment percentage of compensation for the loss in yield due to skips will generally lead to erroneous conclusions.

3. Especially for breeding work and variety trials where the experimental material varies considerably the haphazard use of any adjustment formula may be confusing and may lead the research worker to draw false conclusions from his experiment.

4. The usefulness of any adjustment method is limited to certain conditions. For a small number of missing hills distributed at random, a homogeneous experimental material and a homogeneous field, such a method may give a satisfactory approximation for the plot yield.

5. For large numbers of missing hills it is recommended that no adjustment be made.

6. The occurrence of missing hills must be avoided as far as possible by using first class seed and by applying the best field techniques and practices. If they do occur, then the "normal plant method" suggested by ROEMER (1930) and recommended by SCHLösser et al. (1961) would be recommended. The correction would be made by discarding all the hills that can be affected by the skips, harvesting the rest together and multiplying their average yield by the number of hills which should have been found in the plot to obtain the corrected plot yield. This method of adjustment would give the best estimate of the plot yield and it is highly recommended when space and labour are sufficient.

Up till now the question of how to adjust the yield of plots with missing hills is not yet fully answered. Because of the nature of the problem and the diversity of the factors that influence it, further investigations with several crops and varieties and under varying condition would be highly recommended. 


\section{SAMENVATTING \\ De invloed van misplaatsen in rassenproefvelden}

Gedurende de jaren 1959 t/m 1961 zijn een aantal proeven met mais genomen met het doel de invloed te bestuderen, welke misplaatsen uitoefenen op de omringende planten en na te gaan, door welke factoren het z.g. compensatie-effect wordt beînvloed. De volgende factoren werden beschouwd: grootte en vorm van de misplaatsen, type van beplanting ( 1 of 2 planten per plantplaats), de toegediende hoeveelheid stikstof, de gebruikte hybriden en de klimaatsomstandigheden gedurende de drie proefjaren.

Onder de in Nederland geldende omstandigheden zijn de volgende resultaten bereikt:

1. Er werd een opbrengsttoeneming geconstateerd bij de plantplaatsen grenzend aan een misplaats, zowel bij die gelegen in dezelfde als in de er naast liggende plantrij. De invloed van een misplaats op zijn rechtstreekse buren in de rij (aangeduid als A-buurplanten) was zeer groot.

2. Ofschoon de vorm van de misplaatsen nergens in de literatuur vermeld wordt, is uit dit onderzoek duidelijk gebleken, dat de grootte van een misplaats niet de enige factor is waarmede rekening moet worden gehouden, doch dat men evenzeer dient te letten op de vorm daarvan. De invloed van lege plekken bleek statistisch significant te zijn op het $1 \%$-niveau.

3. Het aantal planten per plantplaats had een significant effect op de invloed van lege plaatsen op hun buurplanten.

Met betrekking tot dit effect vertoonden de diverse hybriden statistisch betrouwbare verschillen blijkend uit een hoog significante interactie tussen aantal planten per plantplaats en hybriden.

4. De verschillende hybriden liepen sterk uiteen in hun reactie op misplaatsen, aantal planten per plantplaats en grootte van de stikstof bemestingsdosis.

5. Er was een duidelijke invloed van jaren en weersomstandigheden op de mate van compensatie van de totale opbrengstderving.

6. Onder de bestudeerde factoren nam het stikstofbemestingsniveau een ondergeschikte plaats in; het reageerde verschillend naarmate de plantdichtheden uiteenliepen.

7. De oriëntatie van de plantplaatsen rondom een misplaats was van veel betekenis voor de compensatie van het opbrengstverlies, aangezien de plantplaatsen gelegen aan de noordzijde een 7.6-9.5\% grotere compensatie te zien gaven dan die aan de zuidzijde. Bij de aan de westkant gelegen plantplaatsen was de compensatie 5.0 à $6.0 \%$ hoger dan bij die aan de oostelijke rand.

\section{CONCLUSIES}

Uit de door dit onderzoek verkregen resultaten en de bespreking van de in het voorgaande vermelde vereffeningsmethoden kunnen de volgende conclusies worden getrokken: 
1. Onder de in Nederland heersende omstandigheden is het effect van misplaatsen niet standvastig. Dit effect is, integendeel, onderhevig aan tal van factoren waaronder grootte en vorm van de lege plaatsen, de toegepaste plantdichtheid (aantal planten per plaats), aard van de hybriden, jaren en klimaatsomstandigheden de voornaamste plaats innemen.

2. Uit het in 1. gestelde vloeit voort, dat de toepassing van vereffeningsformules, berustend op de al te eenvoudige veronderstelling dat de opbrengstderving tengevolge van misplaatsen door een constant compensatiepercentage kan worden vereffend, in het algemeen tot onjuiste conclusies zal leiden.

3. In het bijzonder bij kweekwerk en rassentoetsing, waar het onderzoekmateriaal een aanzienlijke variatie vertoont, kan het lukraak toepassen van welke vereffeningsformule ook de onderzoeker op een dwaalspoor brengen en hem onjuiste conclusies uit zijn proefnemingen doen trekken.

4. De toepasbaarheid van elke vereffeningsmethode is beperkt tot bepaalde omstandigheden. Indien het aantal misplaatsen gering is en deze volgens het toeval verdeeld liggen, het proefmateriaal zowel als het proefterrein homogeen zijn, dan kan door toepassing van zulk een methode een bevredigende benadering van de proefvakopbrengst worden verkregen.

5. In het geval van grote aantallen misplaatsen verdient het aanbeveling in het geheel geen compensatie toe te passen.

6. Het optreden van misplaatsen dient zoveel mogelijk te worden vermeden door gebruik van eerste klasse zaad en door toepassing van de best mogelijke methoden van aanleg en onderhoud. Indien zij toch optreden, verdient de "Normalpflanzenmethode", zoals voorgesteld door ROEMER (1930) en bepleit door SCHLÖsSER et al. (1961) aanbeveling. De correctie wordt in dit geval aangebracht door alle planten, welke mogelijk onder invloed van een lege plek hebben gestaan, te verwijderen, de overige planten te oogsten en hun gemiddelde opbrengst te vermenigvuldigen met het aantal plantplaatsen dat in het proefvak aanwezig behoorde te zijn, ten einde de gecorrigeerde vakopbrengst te vinden.

Door deze correctiemethode zou de best mogelijke schatting van de vakopbrengst worden verkregen. $\mathrm{Zij}$ wordt sterk aanbevolen, mits het oppervlak voldoende groot is en arbeidskrachten in voldoende mate beschikbaar zijn.

Tot dusverre is de vraag op welke wijze de opbrengst van proefvakken met misplaatsen dient te worden gecorrigeerd nog niet volledig beantwoord. De aard van het probleem en de verscheidenheid van de factoren, welke daarop van invloed zijn, maken dat voortgezet onderzoek met verscheidene gewassen en rassen, verricht onder uiteenlopende omstandigheden, sterk de aanbeveling verdient.

\section{ACKNOWLEDGEMENTS}

The present work was carried out at the Institute of Agricultural Plant Breeding (I.v.P.), Agricultural University in Wageningen, The Netherlands. The writer wishes to express his deepest gratitude for his promotor Professor Dr. Ir. J. C. DorsT, the director of the Institute, for his guidance, valuable advice and stimulating criticism 